\title{
Constitutional Adjudication and the Indeterminate Text: A Preliminary Defense of an Imperfect Muddle
}

\author{
Stephen L. Carter†
}

One receives only imperfect justice in this world; only fools, children, left-wing Democrats, social scientists, and a few demented judges expect anything better.

-C. Bradley Walker, III, Associate Justice, United States Supreme Court ${ }^{i}$

I do not deny that we have to muddle. I just believe that not all muddles are identical in shape.

-Arthur Allen Leff ${ }^{2}$

Constitutional theory would be important no matter what constitution we had. It is especially important because we have the Constitution that we do. The Constitution that we have is riddled with provisions best described as indeterminate. They are indeterminate in a particular sense: One who understands the language and laws of the nation can nevertheless find many different meanings in these clauses unless provided with a clear set of interpretive rules. Providing these rules-and thereby providing the substantive underpinning for constitutional adjudication-is probably the most vital task that constitutional theory must perform.

Conventional constitutional theory, however, is thought by some critics to be in extremis. It is said to be poisoned with value preferences disguised as neutral rules. There is no cure, these critics contend, because each conventional theory carries with it the same fatal disease. By setting forth rules of interpretation, modern constitutional theory seeks to set limits on the institution of judicial review. But according to the critics, principled

1985 Stephen L. Carter.

$\dagger$ Associate Professor of Law, Yale University. I am grateful to Enola Aird, Lea Brilmayer, Eric Carter, Owen Fiss, Geoffrey Hazard, Martha Minow, and Jefferey Sellers for their comments, whether enthusiastic or not, on earlier versions of this Article. I have also had the benefit of research assistance from Daniel Ewell.

1. Quoted in W. Murphy, The VICAR of Christ 109 (paper ed. 1980). See infra note 5.

2. Leff, Law and Technology: On Shoring Up a Void, 8 OrTAwA L. REv. 536, 547-48 (1976). 
limits cannot be located in the text of the Constitution-the document that purportedly grants the courts license to do what they do-because the provisions to be interpreted lack clear, inherent meanings. If this is so, the critics continue, then constitutional adjudication as we have come to know it is incompatible with the tenets of constitutionally limited majoritarian government, and hence, by its own terms, is illegitimate. Constitutional theorists generally concede that the conclusion would be right if the premise were. But principled limits are available, they contend, and by finding those limits (and perhaps overturning a few wrongly decided cases) we can rescue constitutional adjudication.

The modern critics of constitutional theory come from a variety of schools and their forms of attack vary. ${ }^{3}$ This essay addresses only one of those forms, a critical enterprise that has been described by one legal scholar and proponent, Alan Freeman, as the advocacy of "negative, critical activity as the only path that might lead to a liberated future." Bits and pieces of the enterprise (which is generally, and sometimes accurately, associated with the Critical Legal Studies Movement) have been given various names, but I prefer one that seems to me most descriptive of what the enterprise is all about: Delegitimation. I choose this word because, ultimately, the critics whose work I address see in the Constitution's indeterminacy and the substantive biases of constitutional doctrine evidence of the illegitimacy not only of what might be called liberal constitutionalism, which includes judicial review, but of the entire structure of liberalism as a coherent political theory.

In this Article, I will briefly describe certain aspects of the delegitimizing assault on conventional constitutional theory, assess what seem to me the most important responses so far put forth, and try to sketch an alternative approach. The approach I will suggest attaches less importance to

3. For some forms of attack other than the one described in this essay-and the approaches listed here far from exhaust the field-see, e.g., R. BERGER, GovernMENT BY Judiciary (1977) (original understanding is best guide); J. ELY, DEMOCRACY AND DISTRUST (1980) (courts should police political process); M. Perry, The Constirution, the Courts, and Human Rights (1982) (judicial decisions form part of evolutionary moral process); L. TRIBE, AMERICAN Constitutional Law (1978) (broad fundamental rights deserve judicial protection). Throughout this Article, I will refer to these critics, as well as those they criticize (often one another), as "conventional theorists," not in any sense to disparage their work, but rather to set them apart from the critics whose work is the subject of this essay and who do not as a rule locate themselves within the conventional universe of discourse in which other constitutional theorists debate.

4. Freeman, Truth and Mystification in Legal Scholarship, 90 YALE L.J. 1229, 1231 (1981). Critical theory in general takes an approach of this lind. See, e.g., D. HeLD, INTRODUCrion To Critical Theory: Horkheimer to Habermas (1980); T. Schroyer, The Critique of DomiNATION (1975). Nothing in this essay should be taken to suggest that the movement I am discussing is in any sense monolithic. See, e.g., Unger, The Critical Legal Studies Movement, 96 Harv. L. Rev. 561, 563 n.1 (1983) (noting distinct strands); Hutchinson \& Monahan, Law, Politics, and the Critical Legal Scholars: The Unfolding Drama of American Legal Thought, 36 STAN. L. REv. 199, 21927 (1984) (same). 
justifying particular results than to justifying the governing structure within which the judiciary plays its peculiar role. This approach is in keeping with the sad and perhaps somewhat unfashionable philosophy of Justice Walker, a process-oriented jurist and advocate of judicial restraint who is a fictitious creation of Walter Murphy. ${ }^{5} \mathrm{I}$ am not so bold as to claim that my approach resolves the problem raised by the delegitimizing critique of conventional constitutional theory, but the approach does, I think, suggest some avenues that conventional theorists who desire to repulse the assault ought to travel.

\section{A Possible Problem}

Criticizing the law must surely be a practice as old as the law itself; criticisms of the Constitution certainly predate the document's ratification. Gonventional critiques, accepting the legitimacy of liberal politics and judicial review, seek to improve the ways in which the judges use the constitutional text in reaching decisions. The conventional critic is confessedly reformist. The delegitimizing critique of the legal system in general, and of constitutional adjudication in particular, differs in style and substance alike from conventional critiques. The delegitimizing critique draws intellectual sustenance from both the critical theory of the Frankfurt School and the movement in literary criticism known as Deconstructionism. As I understand it, Deconstructionism essentially holds that a text lacks a single, objectively determinable meaning. A text's only meaning is the one given by an interpreter, who in turn always reads the text against a particular social and political backdrop. From the Deconstructionist's point of view, to speak of a value-neutral interpretation is to speak nonsense. Thus the Deconstructionist will take a text apart, seeking to expose the fallacies and contradictions in the "approved" interpretations and to show how these past efforts at interpretation are deeply imbued, whether consciously or not, with the values of the interpreters. ${ }^{6}$

5. See W. Murphy, supra note 1, at 98-286. Professor Murphy's remarkable novel paints a marvelous portrait of the traditional judge, who apparently is based loosely on Felix Frankfurter. Justice Walker's jurisprudence emphasizes restraint:

[M]y judicial commission is not a license to read my reasoned values, however deeply felt, into the Constitution's clauses and impose them on the people of the United States. I do not, to be sure, argue that the world is better for my self-restraint; only that the Constitution requires such modesty from judges.

Id. at 243. The quotation on perfect justice which opens this Article actually speaks to a subject broader than mine: Justice Walker is referring to the injustice inherent in life, injustice which in his view the law should not or cannot correct, rather than to any imperfections in the law itself.

6. See H. Bloom ex al., Deconstruction and Criticism (1979); V. Leitch, Deconstructive Criticism: An Advanced Introduction (1983). Deconstructionists generally take the view that approval of an interpretation is a function of power and not of proof. Although aspects of Deconstructionism and of critical theory in general have Marxian roots, it is unnecessary to be a Marxist in order to appreciate the force of many of the arguments. Perhaps needless to add, the Deconstructionist 
The application of this critical style (true Deconstructionists would grind their teeth were I to call it a "method") ${ }^{7}$ to the debate over the legitimacy of judicial review should be obvious. By tradition, liberal political thought has distinguished legal texts from other texts by the peculiar knowability said to attach to the law. Law is supposed to have substantive content apart from what some interpreter might choose to give it. This knowability, which in liberal theory justifies state enforcement of law, has always been a weak link in the chain of argument needed to defend conventional constitutionalism. Not surprisingly, it is here that the delegitimizing critics of constititutional theory-Mark Tushnet is surely the most prolific exemplar ${ }^{8}$ - have chosen to concentrate their attacks. The attacks are now so ubiquitous that the steps in the argument can be rattled off quickly with reasonable assurance of accuracy.

The critic begins with a simple proposition: Although the Constitution tells us in Article VI that it is the society's fundamental law, binding all judges and public officials, it is silent on the further issue of defining interpretive norms. The critic typically attacks a line of Supreme Court decisions purporting to interpret a particular segment of the Constitution. After examining the constitutional clause in question, the critic finds that the clause is like any other text in that it lacks a single inherent meaning. The only "meaning" the clause possesses is the one assigned by the institution that purports to determine its meaning authoritatively, the Supreme Court. There are, the critic insists, neither neutral standards (by which is meant standards that yield consistent results regardless of the values of the reader who applies them) to guide the process of interpretation nor a community of interpreters with the authority (other than the authority defined by the community itself) to enforce a meaning on a dissenting critic. Yet in practice, despite assertions of legal and judicial autonomy, the Court reaches results that tend to support the existing social-political order.

literary critics, like the constitutional delegitimizers, are hardly a monolithic community.

7. There is nevertheless some danger that Deconstructionism has become a method, with all the loss of intellectual rigor and creativity that that term implies. See V. LeITCH, supra note 6, at 262.

8. See, e.g., Tushnet, Critical Legal Studies and Constitutional Law: An Essay in Deconstruction, 36 Stan. L. Rev. 623 (1984) [hereinafter cited as Tushnet, Critical Legal Studies]; Tushnet, Following the Rules Laid Down: A Critique of Interpretivism and Neutral Principles, $96 \mathrm{HARV}$. L. REv. 781 (1983) [hereinafter cited as Tushnet, Following the Rules]; Tushnet, Darkness on the Edge of Town: The Contributions of John Hart Ely to Constitutional Theory, 89 Y ALE L.J. 1037 (1980) [hereinafter cited as Tushnet, Darkness on the Edge]; Tushnet, Truth, Justice, and the American Way: An Interpretation of Public Law Scholarship in the Seventies, 57 TEx. L. REv. 1307 (1979). Much of this Article may consequently be understood as a reaction-although certainly not as a rebuttal-to Professor Tushnet's work.

Also crucial to any appreciation of the work of the delegitimizers are Roberto Unger's general critiques of liberal political theory. See R. UNGER, LAw IN MODERN SOcIETY (1976); R. UNGER, KNowledge AND Politics (1975). It should not be assumed, however, that Professor Unger's quasireligious concept of the community is representative of the views of delegitmizers in general. 
Thus, the delegitimizer concludes, the interpretations that the Court actually places on the clause at issue reflect little more than judicial enforcement of the value choices already reflected in the existing order.

To be sure, the value choices identified by these constitutional delegitimizers are generally more complex than "I think this is a good idea." The point of their analysis is not, or at least not primarily, to show that judges rise in the morning and muse, "Hmm, I wonder how I can use this case as a vehicle for promoting the interests of the corporate liberal state." The more important value choices are those made when an individual chooses really to believe in liberal constitutionalism, which includes the notion of a rule of law based on the Constitution's text, with that law-that constitutional meaning-a discoverable thing, distinct from politics, constraining both sovereign and citizen, not relying on individual values for administration, yet at the same time consistent with the basic tenets of liberalism. An individual who accepts this traditional image of law (so the argument runs) already accepts many of the systemic biases that lead to injustice; certainly she cannot claim that her approach to interpretation is "value-free." Substantive biases in the law, according to the delegitimizers, may reflect particular conscious value choices on the part of the interpreters, but that is largely beside the point. The delegitimizers attach much greater significance to the connection between the institution of law and other aspects of politics and society. Thus the delegitimizers challenge both the hermeneutical approach that assumes the law to be knowable in a value-neutral way and the classical liberal assumption that law stands apart from politics. ${ }^{\circ}$ This delegitimizing critique is frequently presented as a part of a broader assault on what are asserted to be the inherent contradictions, and hence the "dilemmas," of liberalism, which come about as the liberal theorist struggles to avoid the occasionally pernicious results of the majoritarian processes that liberalism extolls. ${ }^{10}$ In short, the delegitimizers say, liberal political thought makes value-neutral adjudication simultaneously necessary and impossible. ${ }^{11}$

In at least one sense the delegitimizers have those they criticize at a disadvantage: Attacking liberalism is considerably easier than defining it. Liberalism is a name that has been used to encompass any number of

9. See Kairys, Legal Reasoning, in The Politics of LAw 11 (D. Kairys ed. 1982); Rabinowitz, The Radical Tradition in Law, in id. at 310; Singer, The Player and the Cards: Nihilism and Legal Theory, 94 YALE L.J. 1, 7 (1984); Tushnet, Critical Legal Studies, supra note 8.

10. See, e.g., Freeman, Race and Class: The Dilemma of Liberal Reform (Book Review), 90 YALE L.J. 1880 (1981); Horowitz, The Jurisprudence of Brown and the Dilemmas of Liberalism, 14 Harv. C.R.-C.L. L. REv. 599 (1979); Parker, The Past of Constitutional Theory-And Its Future, 42 Oнго St. L.J. 223 (1981); Tushnet, The Dilemmas of Liberal Constitutionalism, 42 Oноо ST. L.J. 411 (1981).

11. See generally Tushnet, Darkness on the Edge, supra note 8. 
distinct political theories-some of them contradicting others in important respects-and despite recent ambitious attempts to do so, no one has yet created a grand theory capable of synthesizing all these distinct strands. Thus the critic of liberalism has the advantage of selecting within liberal theory, defining away what makes the critique difficult and defining in what makes liberalism most vulnerable. ${ }^{12}$

Yet I do not mean to suggest that the delegitimizers are simply playing games with words and definitions and taxonomies. Liberal political thought in general and the liberal approach to constitutional adjudication in particular, no matter how they are defined, will remain open to attack. After all, this debate is surely about something. When the rhetoric is brushed aside, that something still seems to be the same old issue: whether liberalism can or cannot cope with the "counter-majoritarian difficulty" posed by the institution of judicial review. For the purposes of this Article, without attempting a comprehensive definition, I will simply say that whatever else liberalism is, it is at least a theory emphasizing individual rights within an essentially majoritarian democracy. The form of liberalism that I take the delegitimizers as most earnestly attacking might be called liberal constitutionalism, ${ }^{13}$ because it presupposes that there exists something-for us, ${ }^{14}$ a Constitution-that sets out with reasonable clarity those rights that the majority cannot trample, and also that there exists something else-for us, a judicial system-that is needed in order to ensure that the Constitution is not violated.

Liberal constitutionalism requires adjudication without regard to the values held by the adjudicators because, if the personal values come into play, then the limitations on majoritarianism are no longer those set forth in the document constituting the government itself, but rather those of a group of individuals with powerful but unchecked opportunity to enforce its own views. The law, in other words, is no longer knowable and preexisting but instead simply another form of policy created by unrepresentative judges. The concept of "neutral principles" simply articulates the ideal to which value-conscious adjudication does violence. ${ }^{15}$ If the principles of adjudication (as against the principles of the law itself) are not

12. Much of the analysis in this paragraph is inspired by Shiffrin, Liberalism, Radicalism, and Legal Scholarship, 30 UCLA L. REV. 1103 (1983).

13. I do not claim the term "liberal constitutionalism" as original; I introduce it at all, despite the risk of reducing the argument to one over proper taxonomy, only to make the current point. The term will rarely appear again in this Article.

14. Although Paul Brest has warned us of the danger inherent in using plural personal pronouns, see Brest, The Fundamental Rights Controversy: The Essential Contradictions of Normative Constitutional Scholarship, 90 YALE L.J. 1063, $1065 \mathrm{n.9}$ (1981), I think the use of "us" is fair when, as here, my reference is to conventional constitutional theorists.

15. The term is a familiar one in constitutional debate, but we sometimes forget that it is only 26 years old. See Wechsler, Toward Neutral Principles of Constitutional Law, 73 Harv. L. REv. 1 
neutral, then the liberal ideal breaks down. This much may seem very obvious, but taking the time to repeat it is important. For this aspect of liberal constitutionalism - the demand that the values of the adjudicators play no role in limiting majoritarian processes-is the one that constitutional delegitimizers attack. According to the delegitimizers, it is the conventional theorists who are simply playing a game, manipulating doctrines they know to be hopelessly incoherent. Or worse, if the conventional theorists believe in their work, then each of them is merely acting out the role of Sisyphus, doomed to push the analytical boulder to the top of the hill, only to see some other analyst come along to knock it down again.

The delegitimizers do not leave the matter to abstract theory; they support their beliefs with concrete and often quite detailed analysis. ${ }^{16}$ Identifying apparent substantive biases in our received constitutional doctrine is not tremendously difficult. ${ }^{17}$ The next step is also quite straightforward. The delegitimizer joins the small army of conventional theorists who will place the Supreme Court's opinion, in even a moderately controversial case, nexi to the constitutional text, and demonstrate, often with some force, that the result does not necessarily follow from the text. But if the result did not come from the text, where did it come from? The delegitimizer has a ready answer: From the biases of the interpreter and from those of the world (the social-political and perhaps psychological context in which the interpretation is made). In this sense, part of the delegitimizing critique, the part that identifies doctrinal incoherence, is the same as the conventional theorist's critique. The conventional theorist, however, is

\section{(1959).}

16. See, e.g., Freeman, Legitimizing Racial Discrimination Through Antidiscrimination Law: A Critical Review of Supreme Court Doctrine, 62 MinN. L. Rev. 1049 (1978); Tushnet, “. . . And Only Wealth Will Buy You Justice. . ."-Some Notes on the Supreme Court, 1972 Term, 1974 WIS. L. REv. 177. Naturally, the critics who prefer a delegitimizing approach are capable of equally detailed analysis in realms other than constitutional theory. Duncan Kennedy's better work exemplifies this tradition. See, e.g., Kennedy, Cost-Benefit Analysis of Entitlement Programs: A Critique, 33 Stan. L. REv. 387 (1981); Kennedy, The Structure of Blackstone's Commentaries, 28 Buffalo L. Rev. 205 (1979) [hereinafter cited as Kennedy, Structure of Blackstone]; Kennedy, Form and Substance in Private Law Adjudication, 89 HARv. L. Rev. 1685 (1976).

17. One example of an apparent substantive bias that I use in teaching constitutional law to firstyear law students compares two decisions handed down the same day. In the first case, Little v. Steater, 452 U.S. 1 (1981), a putative father claimed a right to a state-paid blood test in a paternity action brought by the state to recover its child support payments to the indigent mother. The second, Lassiter v. Department of Social Servs., 452 U.S. 18 (1981), concerned the claimed right of a mother to state-paid legal counsel in a proceeding brought by the state to terminate her parental rights. The nine males then on the Supreme Court ruled unanimously in Little v. Streater that the state was required to pay for the blood test for the putative father. In Lassiter, however, only the four dissenters also believed that the state was required to pay for counsel for the threatened mother. It is at least somewhat bizarre that the same court on the same day found the right of a man to the means needed to disprove paternity and hence avoid child support payments more compelling than the right of a woman everyone agrees is the mother to obtain legal counsel that might help her keep her children. Although there are obviously distinctions between the cases, the suggestion that a possibly unconscious sex bias played a role in the results is, to say the least, not wholly implausible. 
likely to believe that doctrinal analysis can rescue doctrine; the delegitimizer is convinced that analysis must ultimately destroy.

For the delegitimizer, avoiding the reformist label is obviously important and the effort to stay outside the mainstream is often reflected in the critic's choice of language. In reflecting on his own work, Professor Tushnet has put the point nicely:

[U]sing Marxism is a strategy to make it clear that my enterprise is different in kind from, say [John] Ely's or [Laurence] Tribe's. ... [T] There is a strong tendency to force a scholar's work into a standard mold in which critique is taken to be a recommendation for doctrinal change. The use of Marxism is a rhetorical mode that I hope shows that such a tendency cannot fairly be brought to bear on my work. ${ }^{18}$

Not all delegitimizers share Professor Tushnet's chosen "rhetorical mode," but they do share his concern that their work not be mistaken for (or manipulated into) criticism in the reformist tradition. Because they dispute the notion that law is a unique or autonomous institution in society, they see no reason to change the law while leaving other social and political institutions untouched.

The approach taken by the delegitimizers should also be distinguished from what might be called trivial interest analysis, which tries to show how a judge's decisions are guided by her conscious intention to shape the law for the benefit of her own class. Trivial interest analysis has never been terribly convincing-except to those predisposed to accept it-because it is too easy. A critic can always find a way to define the class that includes the judge and the plaintiff if the plaintiff prevails, or the judge and the defendant if the defendant prevails. Imagine, for example, a judge who is hearing a sex discrimination case against a major corporation. The judge is a woman who, prior to her appointment, spent many years as a lawyer in a large corporate firm. If she rules for the plaintiffs, she obviously does so because of the emotional or psychological demands of gender identification and solidarity; if she rules for the defendants, she must be moved by a concern for her benefactors or is perhaps a prisoner of her training, or even a mere slave of capital. The nice thing about criticism of this kind is that the critic can't possibly lose; the problem is that for just this reason, it is completely unconvincing.

18. Tushnet, Deviant Science in Constitutional Law, 59 TEx. L. Rev. 815, 826 (1981) [hereinafter cited as Tushnet, Deviant Science]. 
The delegitimizer differs from the trivial interest analyst partly in emphasis and partly in goal. The emphasis is different, because the delegitimizer stresses the incoherence of the underlying legal-political theory and not the mind of the judge. The goal is different because the interest analyst is likely to be a reformer, whereas the delegitimizer does not believe that reform is possible. The entire point of the delegitimizing enterprise is a negative one, to show why the system can't possibly work the way that conventional theorists say that it should, even if all the actors are perfectly benevolent. The delegitimizing critic insists that the interpretations that the legal system seeks to enforce simply have no basis outside of the systematic biases of the larger society. ${ }^{10}$

Thus when dissecting conventional constitutional theories, the delegitimizer works to refute the contention that the authoritative interpretations of the Constitution have been generated by the value-neutral application of determinate and coherent interpretive rules. Different interpreters with different sets of biases might produce different sets of results, a conclusion which, the critic insists, is incompatible with liberalism's requirement of value-neutral adjudication. Liberalism, according to the critics, demands simultaneously that constitutional adjudication proceed from the text, that it be value-neutral, and that it provide a genuine constraint on the actions of government. As long as an indeterminate text serves as the basis for the adjudication and the constraint, conventional constitutional theory will remain incoherent. ${ }^{20}$ Applying the rules to the indeterminate text in order to find a meaning is a process that simply cannot generate a single, authoritative interpretation, the validity of which can be demonstrated to anyone who understands the law and the language. The rules are capable of generating a multiplicity of meanings for the constitutional text, and there is no value-neutral means for choosing among them. Thus, according to the delegitimizer, conventional theory cannot demonstrate the existence of one best reading of the indeterminate text. One reader's-hence, one judge's-interpretation is as "good" (formally justifiable) as another's. ${ }^{21}$ Yet if every reader is free to act in this fashion, the delegitimizer demands, what then is left of conventional constitutional theory?

If conventional theory is to have lasting significance, theorists must rise

19. See, e.g., Kennedy, Structure of Blackstone, supra note 16; Tushnet, Critical Legal Studies, supra note 8. Representative essays of uneven quality are collected in THE PoLITICs of LAw, supra note 9.

20. See generally sources cited supra note 10 .

21. Perhaps the text is a bit strong. Even the most committed delegitimizer would concede, I assume, that there are boundaries to the universe of discourse-that whatever the equal protection clause might be read to mean, it cannot reasonably be read to mean that the states are prohibited from using the color green in their flags. See infra p. 860 \& note 145. 
to the delegitimizing challenge. ${ }^{22}$ Once one gets past the tendency toward rhetorical excess and occasional mean-spiritedness, ${ }^{23}$ there is considerable force in what the delegitimizers have to say. Those who dismiss the delegitimizers as wild-eyed Marxists do so at their peril. The ad hominem attacks often heard in law school corridors do nothing to refute the central contention of the critics: Unless interpretive rules can be discovered and validated, what we are bold to call constitutional theory will be revealed as a sham, a shell game in which the players have to move fast and make a lot of noise because there is no marble. This central contention should trouble any constitutional theorist who wants to believe (in an intellectual as well as an emotional way) in the legitimacy of American constitutional democracy. We do no service for our ideals by hiding from those who criticize them.

Even if ignoring the delegitimizers did not demand intellectual dishonesty, conventional theorists ought not to do so, given the increasingly wide appeal of their ideas among students and scholars. ${ }^{24}$ The courts, moreover, continue to "discover" fundamental rights in the less determinate provisions of the Constitution, and every fundamental rights decision provides for the delegitimizers another illustration of the value-laden indeterminacy of constitutional law. As has been often and accurately observed, there is no real sense in which the Burger Court is "less activist" than the Warren Court-or in which the Warren Court was "more activist" than previous Courts. ${ }^{25}$ When a politician demands that only "strict constructionist" judges be appointed, the politician is really asking less for the application

22. One possible, if somewhat sweeping, response is to say that at least insofar as it seeks to justify what judges do, constitutional theory is balderdash in the first place, and the delegitimizers' "discovery" of this represents a huge waste of effort. Perhaps this is an answer that would please the delegitimizers, but it ought not to please those who consider theoretical underpinnings important in the analysis of any substantive doctrine.

23. The best (I use the word advisedly) example of this tendency is Tushnet, Dia-Tribe (Book Review), 78 Mich. L. REv. 694 (1980). Professor Tushnet has offered a rather oblique apology for the tone of the essay. See Tushnet, Deviant Science, supra note 18, at 826 n.42. For some delegitimizers, the inseparability of dislike of person and dislike of idea seems to be an important article of faith. Cf. Kennedy, Legal Education as Training for Hierarchy, in THE PoLITICs of LAw, supra note 9, at 40, 60 (some "progressive and left" law students adopt "the denunciatory mode," in which they "hate [their] fellow students for the surrenders"). It is not quite clear, however, whether Professor Kennedy is entirely serious in all of his proposals. See Schwartz, With Gun and Camera Through Darkest CLS-Land, 36 STAN. L. REv. 413, 419 \& n.22 (1984).

24. One may judge in a rough way the growing appeal of the delegitimizing idea by the concommitant growth of the Critical Legal Studies movement. See Gerson, Professors for the Revolution: The Counterculture Enters the Classroom, Nat'L L.J., Aug. 23, 1982, at 1; Trillin, Harvard Law, ThE New Yorker, Mar. 26, 1984, at 53. The Stanford Law Review, to take the most prestigious example, has recently devoted two entire issues (published together as one very thick issue) to the work of critical legal scholars. See 36 Stan. L. Rev. 1, 1-674 (1984).

25. Among the many recent Supreme Court decisions protecting what certainly appear to be "discovered" fundamental rights are City of Akron v. Akron Center for Reproductive Health, Inc., 462 U.S. 416 (1983) (right to choose abortion); Plyler v. Doe, 457 U.S. 202 (1982) (qualified right of education); and Little v. Streater, 452 U.S. 1 (1981) (right to state-paid blood test in paternity suit). 
of a particular hermeneutical approach than for the overturning of realworld policies reflecting a particular ideology. In short, neither many judges nor many politicians seem genuinely opposed to non-neutral judicial activity. Thus, the trend that provides much of the grist for the Deconstructionist mill is not likely to halt.

\section{Some Plausible Solutrons}

\section{A. The Perfectionist Response}

Constitutional theorists, acknowledging the growing need to provide a principled underpinning for what constitutional courts are doing, have recently been marching forth in great numbers to battle for the institution of judicial review and the survival of conventional theory. Building on Herbert Wechsler's appeal for "neutral principles" to guide constitutional adjudication, ${ }^{26}$ but simultaneously recognizing the need for a degree of conscious interpretation, theorists have sought to explain the ways in which many judicial decisions construing the Constitution's less determinate or indeterminate provisions are actually tied to values the Constitution holds dear. $^{27}$

This explanation, really a form of defense, ${ }^{28}$ insists that decisions appearing to the theorist to be morally correct need not be discarded, and that neutral principles to justify these often controversial decisions indeed exist and are discoverable in the document, its history, or some other source, such as the evolving moral standards of the American people or the contemporary representation of the core concerns of the Framers or the grand design that the Constitution is said to effect. The Constitution, in other words, guarantees (or can be read to guarantee) many things that are morally proper. Thus, it seems appropriate to label this defense "the perfectionist response."

By and large, these stalwart defenders of conventional constitutional theory have run into a critical firestorm. By offering the perfectionist response, critics have contended, conventional theorists seek merely to legitimate the decisions they like and to overturn the decisions they don't. More to the point, according to the critics, these conventional theorists try to make sense of a system that is, at bottom, unworkable and incoherent.

26. See Wechsler, supra note 15.

27. The theoretical task might also be fulfilled by demonstrating that the Constitution permits judges to enforce the values that some source other than the Constitution holds dear.

28. This form of defense comes naturally to lawyers. It is what a lawyer does every time she writes a brief. If a lawyer wants to prove that a document "really does" have some particular meaning, she simply constructs the best argument she can and hopes nobody finds the flaws. 
Thus, such recent works as John Ely's Democracy and Distrust, ${ }^{2 \theta}$ Laurence Tribe's American Constitutional Law, ${ }^{30}$ and Michael Perry's The Constitution, the Courts, and Human Rights ${ }^{31}$ have all been criticized by delegitimizers as hopeless efforts at rationalizing the basically incoherent principles of conventional constitutional theory in particular and, not incidentally, of liberal political theory in general. ${ }^{32}$ According to the critics, all of these theories are as value-laden as the presumptively discredited theoretical approach each hopes to replace. Passing the question whether the critics are correct on this point, it is worth noting that in attacking these and other conventional defenses of constitutional theory, the delegitimizers set themselves an easy task. Theoretical works of this kind, for all their energy, perceptiveness, and utility, cannot refute or even withstand the delegitimizing effort because they are designed to fight a different battle. They are written not merely to score points in academic debate, but also to influence real world decisionmakers, decisionmakers whose shortrun judgments affect the fates of the living, breathing individuals who provide the names for landmark cases. Thus, using a Deconstructionist stance to demolish the arguments made in these books-an activity sometimes condemned as "trashing"33_is relatively easy. True, these works and many others like them do seek to place desirable results on a principled plane, but they do not meet and rebut the case actually put by the delegitimizers.

Not all efforts at legitimation are so easily dismissed, however. In this category I would include, for example, the unusual but fascinating vision of Milner S. Ball, who would defend judicial review through a frankly mystical appeal to the metaphor of the body politic. ${ }^{34}$ Like John Ely, Professor Ball would confine his activist judiciary to "[p]rotection of the powerless," an activity that "makes natural sense in a society conceived as an organism."38

Professor Ball draws his provocative theory largely from the Carolene

29. J. ELY, supra note 3.

30. L. TRIBE, supra note 3.

31. M. PERRY, supra note 3.

32. See, e.g., Tushnet, Darkness on the Edge, supra note 8 (reviewing Ely); Tushnet, Dia-Tribe, supra note 23 (reviewing Tribe). The criticism of Professor Perry's book has been more oblique, see Tushnet, Following the Rules, supra note 8, at 811-14 (respectful but dismissive), possibly because conventional criticism had quite adequately picked his argument apart, see Wellington, History and Morals in Constitutional Adjudication (Book Review), 97 HARv. L. REv. 326 (1983) (calling argument inconsistent).

33. This choice of condemnatory language has been attributed to John Ely. See Freeman, supra note 4, at 1229. For a more detailed defense of the practice than Professor Freeman presents, see Kelman, Trashing, 36 STaN. L. REv. 293 (1984).

34. Ball, Don't Die Don Quixote: A Response and Alternative to Tushnet, Bobbitt, and the Revised Texas Version of Constitutional Law, 59 TEx. L. REv. 787 (1981).

35. Id. at 802 . 
Products footnote, ${ }^{36}$ but he does not defend the theory by reference to precedent alone. Carolene Products is in his scheme a clue to the possible, not (as it seems to be, for example, to Professor Ely) an index to the permissible. Professor Ball concedes the delegitimizing points that the courts are largely political policymakers and that reasoning is at best a small part of what they do, but reaches quite a different conclusion: "When the power, politics, and performance of the courts succeed, the judicial word may be realized on a spectrum moving from poetry to divine wisdom." ${ }^{37}$ Professor Ball's search is for room to maneuver, not for limits. In his almost joyous ramble through the works of the Framers and of several Christian theologians, he tries to determine not what the Constitution requires of courts, but what we should require of them. Constitutional theory should, in his view, follow the path set by Karl Barth for Western Christianity: aligning itself with the victims of the system that its institutions have helped spawn. ${ }^{38}$ The problem with the delegitimizing view, he explains, is that it "gives present facts more significance than they deserve." 39 He adds:

The givenness of the created order has never deterred poets from recreating the world out of its constituent parts, recombining the givens to illuminate their significance. Carolene Products offers a tantalizing clue: we may re-create from the courts a normative image of an authentically human system of politics, a situation-transcending picture of society. ${ }^{40}$

The villain for Professor Ball is not the courts, but the scholars whose work both protects and shapes judical decisions. He defends utopian visions for essentially the same reasons that others may defend poetry or art or philosophy or even theology: All are visions of ideal worlds that help us shape our world into what we want it to be. This, he believes, is what scholars should be helping the courts to do. ${ }^{41}$

36. United States v. Carolene Prods. Co., 304 U.S. 144, 152 n.4 (1938). This footnote has been reintroduced into contemporary constitutional debate largely because of John Ely's heavy reliance on it. See J. Ely, supra note 3, at 73-183.

37. Ball, supra note 34 , at 809 .

38. Id. at 796-97.

39. Id. at 811 .

40. Id.

41. Professor Ball's argument is in this sense quite similar to that put forth by James Boyd White, who also acknowledges the indeterminacy, the bias, and the "disgraceful injustices" that characterize the process of constitutional interpretation, but nevertheless believes that the process offers the opportunity for cultural definition and perhaps evolution. See J. WhITE, When Words Lose Their Meaning 273-74 (1984). Professor White's broader theory holds that the author of a text sees herself as an ideal writer whose text is intended for an ideal audience, and that the interpretative task is to discover each. He finds in the rendering of opinions the judge's opportunity to seek these ideals. Id. at 269-70. 
Professor Ball is certainly not the first scholar to see the analogy between Supreme Court Justices and high priests. ${ }^{42}$ Those who follow the delegitimizing debate should, however, take careful note of the way in which he turns the critique of liberalism back on itself. Mark Tushnet and others find inconsistencies, weaknesses, and evils in the system and call for a holy war; Professor Ball sees the same problems and calls for sacrifice and redemption as we try to make America over into something closer to our professed ideals. For Professor Ball, the "we" who should make America over quite explicitly includes the courts.

Professor Tushnet, in a brief response, ${ }^{43}$ has already noted one difficulty with Professor Ball's thesis: It assumes that "we" really do want to recreate America in a different vision, even though "it is at least as plausible to think that America has been America, unattractive as that thought may be." ${ }^{\prime 4}$ Yet that sad possibility ought not to be the main delegitimizing response. The real problem, from the delegitimizing point of view, is that if Professor Ball really believes that he has drawn up a program for reform through a reinterpretation of the judicial process, then he is proposing to work within the existing system. If he plans to do that, then he must still find some endogenous legitimizing principle for courts to act in the fashion he prefers. If he cannot, he has no strong response to the charge that he really wants the courts to make America over in his own image of the way things ought to be.

Another of the more earnest and thoughtful among recent efforts to respond directly to the delegitimizers has been that of my colleague Owen Fiss, who has argued that the delegitimizing effort, particularly the Deconstructionist critique, cannot fairly be applied to efforts at construing and applying the clauses of the Constitution. ${ }^{45}$ In the first place, Professor Fiss contends, constitutional adjudication-the interpretive activity taking the Constitution as its text-proceeds within a well-defined interpretive community of lawyers, judges, and scholars. ${ }^{46}$ The members of this community, moreover, share a general norm-the commitment to the rule of law-that is sufficient to generate acceptable and enforceable rules of interpretation for the document. ${ }^{47}$ Thus at least within the community, it is fair and accurate to speak both of interpretations that are authoritative, meaning that the community agrees to be bound by them, and of interpretations (not necessarily the same ones) that are correct, meaning that they

42. See, e.g., Lerner, Constitution and Court as Symbols, 46 YALE L.J. 1290 (1937); Levinson, The Constitution in American Civil Religion, 1979 SuP. CT. REv. 123.

43. Tushnet, Deviant Science, supra note 18.

44. Id. at 826 .

45. Fiss, Objectivity and Interpretation, 34 Stan. L. REv. 739 (1982).

46. See id. at 745-48.

47. Id. at $748-50$. 
are generated through proper applications of the community's agreed rules. ${ }^{48}$

This response to the delegitimizers is optimistic but ultimately incomplete. As Professor Fiss himself recognizes, the answer works only if all members of the community really do endorse the rules of interpretation of which he writes. ${ }^{49}$ Unfortunately, that just is not so. There are, for example, about as many different ways of applying a rule calling for discovery of "the original understanding" as there are arguments for and against applying the rule in the first place. Conventional constitutional theory would be more easily defended if the community agreed on the interpretive rules, but in fact, the battle over the rules has been central to the debate. ${ }^{\mathrm{J0}}$ That is why I said at the outset that all constitutional theories seem to carry the disease.

More than that, identifying the legal community as the relevant interpretive community is in some ways an awkward move. The legal community, one supposes, includes those who have been trained, in the common phrase, to "think like a lawyer." Legal education does spend some time inculcating norms of construction, but it also teaches the manipulation of doctrine. A legal education is more than a license to interpret the law: It is also a license to try to make it. There is no way to tell whether the lawyers who argued Brown v. Board of Education ${ }^{51}$ actually believed that a straightforward application of widely shared rules of construction would "prove" that the Fourteenth Amendment "really did" prohibit segregation. It may safely be asserted, however, that even had they disbelieved, the lawyers would still have been in court. Their legal arguments challenged segregation's constitutionality, but their motive force was surely segregation's immorality.

Professor Fiss would respond, I think, that the subjective intent of an individual lawyer to manipulate doctrine is irrelevant, because the entire legal community accepts the rule of law in general and the finality of the decisions of the Supreme Court in particular. ${ }^{52}$ But he admits that the acceptance of the authority of the Court is not really tied to a perception that the Court is "right." ${ }^{\text {"53 }}$ In other words, the interpretation the Justices place on the text may be simultaneously incorrect and authoritative. If that is true, then to speak of widely accepted canons of interpretation is

\footnotetext{
48. Id. at $751-58$.

49. Id. at 745 .

50. See infra pp. 858-61.

51. 347 U.S. 483 (1954).

52. See Fiss, supra note 45 , at 750 . This acceptance does not of course mean that no one seeks to overturn decisions of the Supreme Court. It does mean that those who counsel disobedience as a weapon are usually treated as subversive.

53. Id. at $747-49$.
} 
somewhat misleading. The only thing the community ultimately accepts is the authority of the Court. The existence of authority without principle, however, is the very essence of the delegitimizing critique. ${ }^{54}$ Unless the legal community and the authoritative interpreter share the same interpretive rules, the delegitimizers have a point: The interpreter, although its views are accepted as authoritative, is ultimately without guiding principles-or at least is not bound to follow them-and hence will not necessarily enforce the discoverable law. Conventional theory might well withstand the critical assault on legitimacy if there existed a legal community sharing a consensus on proper rules of constitutional interpretation. It is fairly evident, however, that no such community exists.

The answer offered by Professor Fiss is incomplete for another reason as well, a reason that in many ways goes to the heart of the delegitimizing critique. The answer assumes that the Constitution is nothing more than a species of law. The assumption that the Constitution is a legal document is plainly crucial to most constitutional theories. ${ }^{\mathrm{sb}}$ The assumption also makes the argument against the delegitimizers quite an easy one: As long as one accepts both the notion that the Constitution is a species of law and the vision of lawyers as people trained to understand the law, it is sensible to refer to the legal community as the relevant interpretive community (and hence to the norms of the legal community as the relevant interpretive norms) when one considers the meaning of the Constitution.

But while the Constitution is indeed a species of law, it is also much more than that. The Constitution establishes political as well as legal relationships. ${ }^{56}$ It is an instrument of governance, setting out the structure of the government and many of the value choices of its authors. The structure it creates often calls for the interplay of political forces rather than legal arguments. To the extent that the Constitution does more than establish a system of legal relationships, to the extent that it is a political

54. My colleague Lea Brilmayer has suggested that this version of the delegitimizing critique might be avoided by treating constitutional adjudication as a delegated power. Similarly, my colleague Geoffrey Hazard has suggested that we treat the Court as a legislature. See infra p. 837-38. These suggestions, even if persuasive, would not avoid the need to determine whether there has been popular consent to the judicial role, unless one accepts Professor Fiss' suggestion that citizens are bound by the acceptance of the benefits of the society to consent to all parts of the system of governance. See infra pp. $838-39$.

55. This assumption was indispensible to John Marshall's structural justification for judicial review in Marbury v. Madison, 5 U.S. (1 Cranch) 137 (1803), a justification that some conventional theorists have echoed. See Rostow, The Democratic Character of Judicial Review, 66 HARv. L. REv. 193, 194-200 \& n.2 (1952); Wechsler, supra note 15, at 2-10; C. BLACK, StruCture ANd RelATIONSHIP IN CoNSTITUTIONAL LAW 69-77 (1969) (dubitante).

56. For my earlier effort to assess this idea (which I certainly do not claim as original), see Carter, The Political Aspects of Judicial Power: Some Notes on the Presidential Immunity Decision, 131 U. PA. L. Rev. 1341 (1983) [hereinafter cited as Carter, Judicial Power]. 
document, a critic may plausibly challenge the selection of the legal community as the relevant community of interpreters. If the Constitution sets out the fundamental political relationships of the society but does not in unambiguous terms grant ultimate interpretive authority to the legal community, then how can the legal community defend against the criticism that it has arbitrarily proclaimed itself the ultimate interpreter of constitutional meaning? After all, as Paul Brest points out in his comment on Professor Fiss's essay, lawyers and legal scholars, like it or not, "are members of a ruling elite," rule of law really seems a commitment to the rule of our law."B8 If, moreover, the Constitution is viewed as setting forth a system of government as well as a legal system, then the citizen ruled by that government might easily claim a right to an interpretation of her own. If the Constitution, our society's authoritative text, really does not include guides to its own construction, then why should the citizen be bound by the inevitably biased and arbitrary interpretations placed on this authoritative text by members of a legal community with no demonstrably justifiable claim to ultimate authority and - even granting its authority-no shared consensus on rules of interpretation?

One effort to avoid these obstacles is that of another of my colleagues, Geoffrey Hazard, who suggested a few years ago that we can pass these questions about the legitimacy of judicial review by treating the Supreme Court as a legislative body, not a judicial one. ${ }^{58}$ This view of the Supreme Court is useful, because it acknowledges the dual political and legal nature of the Constitution. At the same time, it preserves the special role of the Court, even in this mixed legal-political system. Professor Hazard's argument relies heavily on the ways in which the Court, in composition, rules of procedure, and scope of activities, resembles a legislature. ${ }^{60}$ The difficulty with Professor Hazard's argument, acknowledged frankly in his text, is that if one strips away the pretense that the Justices are jurists, it is not easy to see how their discretion is bounded. Professor Hazard contends that the Court's discretion is limited not only by its rules of procedure $^{61}$ and its inability to enforce its own judgments, ${ }^{62}$ but by its constituency - the lawyers, journalists, governors, and so on who read and

57. Brest, Interpretation and Interest, 34 STAN. L. Rev. 765, 771 (1982).

58. Id. at 772 .

59. Hazard, The Supreme Court as a Legislature, 64 CoRnell L. Rev. 1 (1978).

60. Id. at 17-27. Professor Hazard's argument also relies on a reading of the history of the relevant constitutional provisions. See id. at 2-8. I have not revisited the historical materials on which Professor Hazard relies, but certainly have no reason to doubt his understanding.

61. Id. at 16-17.

62. Id. at 13 . 
respond to its opinions. ${ }^{63}$ Underlying Professor Hazard's theory must be an assumption that the right to legislate in the way he describes has been delegated to the Court by the people who presumably rule, and not merely by the intellectual elite whom he correctly identifies as the Court's primary constitutency. ${ }^{64}$ Otherwise the delegitimizer could respond that elite approval of the role and work of the Court is not sufficient to justify it within the framework of an essentially majoritarian theory of politics such as the one I have described. If I read Professor Hazard correctly, however, he still in the end runs up against the delegitimizing shoals, because his argument does not respond to the claim of the delegitimizers that this judicial power, however described, lacks legitimacy in a majoritiarian process. In other words, it is necessary as well to explain how the consent has been given.

Again it is Professor Fiss, in another article, who has suggested the strongest response. ${ }^{65}$ The citizen is bound, he contends, because once one accepts the benefits of citizenship, one is also required to accept the burdens. There is only one system of government in the United States, and consent to any part of the system is the same as consent to the whole. Gitizens cannot pick and choose. ${ }^{66}$ This Lockean concept of the nature of consent is terribly tempting, as it seems to ask so little and to promise so much. ${ }^{67}$ It is reminiscent of one frequently repeated argument on why

63. Id. at $22-27$.

64. An alternative is to contend that the members of this reasoning class are the Court's sole constituency, and that members of the larger society-individuals who by hypothesis do not read the Court's opinions and know little or nothing about its work-obey the judicial pronouncements only because this reasoning class tells them to. Cf. R. SENNETT, Authoriry 165-90 (1980) (discussing governance by "chain of command"); Petrick, The Supreme Court and Authority Acceptance, 21 W. PoL. Q. 5 (1968) (argument addressed specifically to Court). Although such a proposition holds a degree of common sense appeal, it is difficult to say where (or how) one ought to look for empirical support for it.

65. Fiss, The Supreme Court, 1978 Term-Foreword: The Forms of Justice, 93 Harv. L. REv. 1, 37-39 (1979).

66. See id. at 38 :

Legitimacy does not depend on popular approval of the institution's performance, and even less on popular approval of the processes through which that performance is rendered. It is the legitimacy of the political system as a whole that depends on the people's approval, and that is the source of its democractic character.

67. Obviously, this description is incomplete. One may respond, as did one of my colleagues upon reading this sentence: "Asking of whom and promising to whom?" The question, although a fair one, may be beside the point. Answering the delegitimizing critique that judicial review is inconsistent with aspects of liberalism does not require assertion that the results a liberal system may achieve are perfect. If on the other hand one is impressed by the delegitimizing argument that liberal society and institutions are inherently unjust, then determining the allocation of benefits and burdens becomes more important. Liberalism, however, does not deny the freedom of the observer to criticize the results wrought by the system. On the contrary, the liberal observer can stand outside the system and judge its ideals before deciding whether to participate in the society's effort to achieve them. This freedom is important in distinguishing liberalism from many other ideologies. See infra pp. 868-69.

This response does not necessarily assume the uniqueness of America. $C f$. Tushnet, Deviant Science, supra note 18, at 826 (suggesting that those in power in America will fight as violently to retain that status as those in power anywhere else). But the response might shift the burden, at least a bit, to 
justice permits that presumptively innocent white males be made to bear the costs of affirmative action programs. The costs are societal costs that have been incurred by the entire United States, in effect, as a purchase price for years of discrimination; bearing one's share of those costs is an obligation of citizenship. ${ }^{68}$ I would much prefer to be able to accept Professor Fiss's answer uncritically, because it offers a form of support for programs I consider morally imperative.

Appealing though the obligation argument might seem, political theorists have long pointed out the fairly strong argument to the contrary. In general, the law refuses to find consent in the absence of agreement. If contract law, for example, will not presume consent in the absence of agreement with respect to what might be called economic rights, it is at the very least troubling to presume consent in the absence of agreement with respect to what might be termed political rights. Certainly there has never been a meeting of the minds between the ordinary citizen and the putative interpretive community, the lawyers. In the absence of agreement, the dissenting critic might once again view the legal community's claim of ultimate authority as an arbitrary usurpation of power. If all of this is so, then there is no agreement between governor and governed, and it is not clear why anyone outside the community that agrees to call itself authoritative is bound by that community's edicts. ${ }^{69}$

If the identification of an interpretive community ultimately rests on this notion of consent, and if the consent argument, at least in its pure form, falls short, then neither approach will without more lead to legitimacy. Their weaknesses, however, are only in their immediate ambition. Like other arguments against constitutional delegitimation, both ultimately involve too many value preferences. Put otherwise, in response to the charge that the system is imperfect, defenders of conventional constitutional theory have sought all too often to demonstrate its perfection. Yet just as we cannot judge moral perfection without the benefit of absolute moral standards, so on the issue of systemic perfection, the jury is out, and

the other side, asking the delegitimizers to propose an alternative social organization. See Johnson, Do You Sincerely Want to Be Radical?, 36 STAN. L. REv. 247 (1984) (Critical Legal Studies fails as truly radical movement because of its inability to articulate coherent and achievable alternative vision).

68. See, e.g., B. BITTKer, The Case for Black Reparations (1973); Black, Civil Rights in Times of Economic Stress-Jurisprudential and Philosophic Aspects, 1976 U. ILL. L. F. 559; Carter, The New Affirmative Action, The Old Genetics, and The Problem of Remedy (unpublished work-inprogress).

69. Revolution may of course come from within as well as without. Just as it is not clear why anyone outside the interpretive community is bound by its edicts, it is also not clear why anyone inside the community is bound. After all, the delegitimizers, who launch an important intellectual challenge to legal and judicial authority, are largely members of the legal (interpretive) community. 
unless Mark Tushnet's Einstein of the moral calculus shows up, ${ }^{70}$ is likely to remain out for the foreseeable future.

All sides apparently agree that the solution should be sought in or near the Constitution itself. But the arguments made so far by conventional theorists have yet to demonstrate how the document itself refutes the case put by the delegitimizers. This failure, however, hardly forecloses the prospect of refuting the delegitimizing arguments. On the contrary, the traditional efforts at refutation have failed largely because they concede the major premises of the critics, that is, that liberal theory can legitimate the institution of judicial review only if it can uncover a single, authoritative interpretation for the indeterminate text. I would suggest, however, that even in a legal-political system less than demonstrably perfect, there are other paths that might lead to the top of the legitimizing hill, paths that some observers have already started to travel.

\section{B. The Political Response}

Ironically, one of those paths is suggested by a comment made by Paul Brest, himself something of a delegitimizer, in his response to Professor Fiss' argument against constitutional Deconstruction. In considering the distinction between literary interpretation and legal interpretation, Professor Brest writes:

[B]oth the consequences of interpretation and the power of the interpretive communities over nonmembers are vastly different. That is a matter of politics, and the lesson I carry away from contemporary literary and social theory is that the line separating law from politics is not all that distinct and that its very location is a question of politics. $^{71}$

The proper connection between law and politics is a point of considerable contention in the academic community. Liberal political thought resists the idea that the law is necessarily no more than the continuation of politics by other means. On the other hand, only the purest formalist would suggest that law in general and adjudication in particular exist entirely apart from politics. There is plainly some degree of overlap and reinforcement of each by the other. Deciding how great that overlap is or ought to be an important task. Conventional constitutional theorists, however, tend

70. See Tushnet, Darkness on the Edge, supra note 8, at $1044 \mathrm{n} .29$ (citation omitted): "One could have a natural law theory of sufficient specificity to explain why nonunanimous jury verdicts are permissible unless the jury size is six; perhaps some Albert Einstein of the moral universe will someday discover (not develop) that theory." The point of the analogy is that however much we might believe that moral norms are ultimately arbitrary, we cannot possibly know that they are. But see Leff, supra note 2 , at $538,545-46$ (modern ethical theory depends for validation on reference to terms outside the system, and thus can only be arbitrary).

71. Brest, supra note 57 , at 773 . 
to avoid this task or to approach it only obliquely. ${ }^{72}$ Their search has been instead for guiding principles in determining the "true" meaning of the text.

Still, politics, at least in the popular sense, often serves a function in conventional constitutional theories. Its function is generally one of justification. The Supreme Court is justified in doing what it does-whatever that might be-because, after all, if it goes too far, the people will stop it, by amending the Constitution to overturn its judgment, by altering its jurisdiction, or by withdrawing their consent to the Court's role. ${ }^{73}$ This approach offers the wonderful advantage of lifting from the theorist the burden of justifying any particular proposal by reference to values the Constitution itself creates. Instead, the theorist can refer self-consciously to political and moral philosophy, using this crutch-the people as check-to evade the charge of arbitrary usurpation of authority.

Actually, the crutch cannot bear much weight. The Constitution is not easily amended and the constitutional decisions of the Supreme Court are not easily overturned. To point to the availability of the amendment process is attractive but also too pat. The complexities of that process, as set forth in Article V, are such that it cannot be used easily. ${ }^{24}$ In this unwieldiness lies part of the charm of the process, but also part of its weakness. People raised to accept the rule of law hold personal belief systems that are remarkable in their malleability. Very often, by the time opponents of even a very unpopular decision can crank up the old amendment process, most of the steam will have gone out of the opposition. The American people, basically conservative in matters challenging the system under which they live, will have come to accept the new status quo. ${ }^{75}$

72. I mean by "obliquely" only that locating the intersection between law and politics is rarely the purpose of a conventional theorist's inquiry. I do not mean to suggest, however, that conventional theorists never seek to engage in serious dialogue with delegitimizers. In addition to Professor Fiss' Stanford Law Review article, see supra note 45, discussed supra pp. 834-36; see, e.g., Ball, supra note 34; Schwartz, supra note 23; Shiffrin, supra note 12.

73. See, e.g., A. Bickel, The Least Dangerous Branch (1962) [hereinafter cited as A. BickEL, LDB]; M. PERRY, supra note 3, at 125-39; L. TRIBE, supra note 3, at 49-51; cf. J. ChOPER, Judicial Review and the National Political Process (1980) (viewing Court as one actor in political process).

74. The question whether Congress or the courts should unravel the complexities of Article V has recently led to an important exchange between Walter Dellinger and Laurence Tribe. See Dellinger, The Legitimacy of Constitutional Change: Rethinking the Amendment Process, 97 HARV. L. REv. 386 (1983); Tribe, A Constitution We Are Amending: In Defense of a Restrained Judicial Role, 97 Harv. L. Rev. 433 (1983); Dellinger, Constitutional Politics: A Rejoinder, 97 Harv. L. Rev. 446 (1983). As will become clear in Part III of this Article, I cannot escape the feeling that robust and closely reasoned doctrinal analysis of this sort is tremendously important if the effort to rescue constitutional theory is to succeed.

75. Even if the people do not accept the status quo, the amendment process will generally be stalled if most members of Congress prefer not to amend. For interesting analyses on how power is shared and balanced in the amendment process, see Black, The Proposed Amendment of Article V: $A$ Threatened Disaster, 72 YALE L.J. 957 (1963); Dellinger, The Recurring Question of the "Limited" 
I do not mean to suggest that no judicial decision remains unpopular long after it has been handed down, but rather that mere unpopularity--even if broad and deep-cannot by itself bring about constitutional amendment. Despite overwhelming public support, constitutional amendments prohibiting state-sponsored sex discrimination, permitting organized prayer in public schools, and mandating a balanced federal budget, have yet to be adopted. ${ }^{76}$ The failure of the school prayer amendment in particular illustrates the practical weakness of Article V: Even the views of a vast and diverse majority of Americans, views consistently held over two decades, may not be enough to force constitutional amendment. ${ }^{77}$ Too many other constituencies have too many opportunities to block action. In the 1980 's, Article V is very nearly a dead letter. ${ }^{78}$ The contention that it provides a realistic check on judicial activity is at best wishful thinking, certainly somewhat naive, and at worst disingenuous.

Pointing to a hypothetical power to alter the jurisdiction of the federal courts is not much of an answer either. Too many purists will insist that no significant measures of this kind can possibly be constitutional, ${ }^{79}$ and even very strong public feelings on varying issues have yet to move the modern Congress to enact legislation purporting to curb the courts in a serious way. ${ }^{80}$ The theorist might respond that the power should be used

Constitutional Convention, 88 YALE L.J. 1623 (1979).

76. Even in the wake of the 1936 election and the apparent popular repudiation of constitutionally mandated laissez faire capitalism, the Roosevelt Administration decided that amending the Constitution to overturn unpopular Supreme Court decisions would be too difficult, perhaps impossible. The court-packing plan was chosen instead. See Lcuchtenburg, The Origins of Franklin D. Roosevelt's "Court-Packing" Plan, 1966 Sup. CT. REv. 347, 378-84.

77. In 1962, the year the Supreme Court outlawed organized prayer in public schools, $79 \%$ of poll respondents (parents of students) said that they approved of "religious observances" in public schools. 3 G. Gallup, The Gallup Poll: Public Opinion 1935-1971, at 1779 (1972). In 1975, asked specifically whether they favored a constitutional amendment to permit prayer in the public schools, $77 \%$ of respondents (adults over 18) said yes. 1 G. Gallup, The Gallup Poll: Public OpINION 1972-1977, at 503 (1978). In 1983, of the 82\% of respondents who indicated that they were aware of the proposed constitutional amendment to permit voluntary prayer in public schools, $81 \%$ said that they favored it. The Gallup ReP. No. 217, at 17-19 (Oct. 1983).

78. For a fascinating effort to give the amendment process new life, see Ackerman, The Storrs Lectures: Discovering the Constitution, 93 YALE L.J. 1013, 1051-72 (1984). Unfortunately, Professor Ackerman's approach suggests interpreting Article $\mathrm{V}$ in a way that gives it a force and a meaning well beyond its literal (or intended) terms. Professor Ackerman's creative argument strays near the edge of the delegitimizing precipice. To see why his approach may be dangerous, see infra p. 864 .

79. See, e.g., Baucus \& Kay, The Court Stripping Bills: Their Impact on the Constitution, the Courts, and Congress, 27 VILL. L. REv. 988 (1982) (efforts to alter jurisdiction represent assaults on constitutionally mandated judicial independence); Eisenberg, Congressional Authority to Restrict Lower Federal Court Jurisdiction, 83 Y ALE L.J. 498 (1974) (lower federal courts must retain sufficient jurisdiction to protect constitutional rights); Sager, The Supreme Court, 1980 Term-Foreword: Constitutional Limitations on Congress' Authority to Regulate the Jurisdiction of the Federal Courts, 95 Harv. L. REv. 17 (1981) (Congress cannot touch Supreme Court's inherent jurisdiction over constitutional controversies).

80. During the Nixon Administration, Congress did enact a few rather weak limitations on federal jurisdiction in public school integration cases. It does not appear that these measures have had any substantive effect. See G. Gunther, Cases and Materials on Constrtutional Law 773-74 
only sparingly, that the mere threat of its use will be sufficient to rein in a rampaging court, but that rather popular answer is not really convincing. In the first place, it is far from clear precisely why the use must only be sparing. Dictatorship is still dictatorship, even though it only sometimes oppresses, and a court may be acting irresponsibly, even though it only sometimes strays. In the second place, the power to control jurisdiction (if the power exists ${ }^{81}$ ) is not one that has been used sparingly; it is one that in modern times has not been used at all. To speak of such a power as nevertheless lurking and forcing the Justices to take care is a bit like asserting that the lurking veto power of the British monarch serves as a moderating influence on Parliament. Both statements are formally correct but realistically irrelevant.

A more sophisticated form of the political response, usually traced to Alexander Bickel, points out that in the long run, the courts cannot enforce their judgments without the good will of the people in general and of the other branches of the government in particular. ${ }^{82}$ On this view, the ultimate brake on the courts is the judges' fear that if they go too far they will be ignored. To use the popular metaphor, if the courts squander their scarce constitutional capital, they will have none left when they need it most. ${ }^{83}$ Perhaps even some Justices of the Supreme Court believe this. There is evidence-although it is thin-that the Justices have occasionally retreated on controversial issues in the face of massive and organized opposition to their edicts. ${ }^{84}$

The major flaw in this argument is that if judges really do retreat when public opinion runs too heavily against them, or if they hesitate to issue unpopular decisions in the first place, then they risk trivializing their role. A constitutional court that acts only when its judgments are popular can hardly be regarded as a functioning guardian of constitutional values that majorities might want to ignore. The defender of this argument would no doubt respond that by conserving their constitutional capital, the courts

(10th ed. 1980).

81. When I say "if the power exists," I am using only a shorthand for "if the application to Article III of my preferred hermeneutical approach yields a construction supporting the exercise of the power"-which is a bit wordy for a parenthetical. My preferred hermeneutical approach for such structural clauses as Article III is set out very briefly infra pp. 855-64.As I hope will become apparent, I would restrict this approach to adjudication under the Constitution's relatively determinate clauses.

82. See A. Bickel, LDB, supra note 73; A. Bickel, The Morality of Consent (1975) [hereinafter cited as A. BiCKeL, MoRAlitry].

83. But see Tushnet, Following the Rules, supra note 8 , at 807 (critiquing this argument).

84. For two views on this phenomenon, compare G. Rosenberg, Congressional Control of the Federal Judiciary Through Court-Curbing (May 1983) (unpublished essay on file with author) with Nagel, Court-Curbing Periods in American History, 18 VAND. L. Rev. 925 (1965); see also S. Goldman \& T. Jahnige, The Federal Courts as a Political System 237-86 (2d ed. 1976) (assessing "feedback" received by federal courts). 
will be able to act when they must, which is to say, when the Constitution itself (as opposed to the self-conscious preferences of the judges) demands action. There is obviously something to this argument; not even the most activist judge seeks willy-nilly to use the judicial process to impose on the nation all her views on proper public policy. ${ }^{85}$ Perhaps the constitutional capital argument is then correct, although it is difficult to imagine how it might be tested empirically. Even if true, however, the constitutional capital argument presupposes that there are both "little" and "big" constitutional violations and that anybody can tell which are which-else the judges could not decide which to let pass and which to halt. ${ }^{86}$ That presupposition in turn gives something of the lie to the argument that adjudication proceeds from widely accepted canons of interpretation. ${ }^{87}$

The argument also has a weakness of another kind. In the end, government in America rests on the public perception that the rulers act in accordance with law. ${ }^{88}$ For better or worse, generations of Americans have been socialized into accepting the interpretive authority of the legal community. Thus, it is not easy to picture the withdrawal of consent from that system merely because the Court's decisions might be unpopular. Nor is it in the interest of other governmental actors to ignore those decisions too often or to encourage disrespect for the Court as an institution. If the prestige of the Court drops, so does the prestige of the Constitution with which it is so closely identified ${ }^{89}$ And if the prestige of the Constitution drops, then the other governors-who purportedly govern by and through that document-may lose prestige as well.

In this sense, Professor Fiss' notion of consent is quite cogent: There is in America only one system of government, and people are taught to accept all of it. Wean them from any part of it, and they might begin to assert extraordinary independence. Like many truths, this one carries with

85. For a rather fanciful expansion of this argument, see Carter, Judicial Power, supra note 56, at $1380-83$.

86. Perhaps a judge could halt only the "clear" constitutional violations, sustaining the challenged government action if she considers its status "unclear." Indeed, calls for judicial restraint of this sort are common. Unfortunately, this plan would be more a description than a guide: I suspect that nearly any judge who has struck down an act of government would insist that its unconstitutionality was as clear as a thing could be. But see Goldwater v. Carter, 444 U.S. 996, 997-1002 (1979) (Powell, J., concurring in judgment) (calling for adjudication even in admittedly difficult cases).

87. Professor Hazard has suggested that this problem might be circumvented by conceding rather than struggling against the Court's need to take account of the likelihood that its opinion be obeyed, and making that need a canon of construction to which the Justices will ordinarily make reference in the process of adjudication. See Hazard, supra, note 59, at 15.

88. I acknowledge once again, as I have in my earlier work, my debt to my student Ellen Shadur for providing the elegant phrasing of this point. See E. Shadur, The Nature of Judicial Review 6 (Oct. 1982) (unpublished essay on file with author).

89. See id. For other versions of this argument, see, e.g., A. Bickel, LDB, supra note 73; Burt, Constitutional Law and the Teaching of the Parables, 93 YALE L.J. 455, 474-76 (1984); $c f$. Adamany, Legitimacy, Realigning Elections, and the Supreme Court, 1973 WIS. L. REV. 790, 791 ("Adoration of the Constitution soon became adoration of its guardians, the Justices . . . ."). 
it the seeds of tragedy: Another word for the form of assertion that I mean is revolution. For many constitutional delegitimizers, this is precisely the point. If the inherent contradictions in the traditional arguments for judicial review (and in the rest of liberal political theory) are exposed, if the government is shown to be ultimately lawless, and the justification for its authority a sham, then no morally defensible alternative to revolution exists. ${ }^{30}$

In general, I suspect that conventional constitutional theorists recognize this: For some of them, it no doubt provides an important incentive for their work. One response to this problem has been, in effect, to deny its causes, to try to rework constitutional theory in a way that seems not to admit of arbitrariness, by carrying the notion of consent a bit further than usual. The temptation is strong to retreat to the Bickelian position, reducing most of morality to the morality of process. ${ }^{91}$ After all, classical liberalism does deny the innate superiority-perhaps "correctness" is a better term-of most ideas other than self-government. ${ }^{92} \mathrm{~A}$ people that participates in its governance (as opposed to one that passively accepts) might be seen as simultaneously fulfilling the liberal ideal and also consenting in an active, understanding way to the system under which it is governed. On this view, the inquiry would turn at least a little from the perfection of the system toward its efficacy in permitting and ensuring active participation by the governed.

There is a degree of poignancy in this effort, because it often requires the sacrifice of positions that the theorist espousing it holds dear. ${ }^{93}$ Following this path up the hill, however, means finding a way around two rather massive obstacles. The first and perhaps the more obvious is that whatever its status among legal and political philosophers, the issue of whether the American democracy truly delivers self-government remains

90. When I say "morally defensible," I am obviously looking beyond the judicial process and selfconsciously invoking higher law as a weapon against the government. If the liberal state is to function as a democracy, it is important not to do this too frequently. See infra pp. 868-69 \& note 168.

91. See A. Bickel, Moral.rTy, supra note 82 , at 123 . Obviously, the temptation to make this reduction is strongest among the members of the reasoning class, see supra note 64 , who often see themselves as leading participants in the pre-legislative dialogue that is contemplated under a theory of process-as-morality.

92. The growth of technological and other forms of expertise may be pushing American society-and certainly American government-away from this classical precept. For a brief critique of this possible trend, see Carter, Separatism and Skepticism, 92 YALE L.J. 1334 (1983). The delegitimizers also are disturbed by the increase in policymaking based on purportedly objective analysis. See Kairys, supra note 9, at 17 ("In many areas of our lives, essentially social and political judgments gain legitimacy from notions of expertise and analysis that falsely purport to be objective, neutral, and quasi-scientific.").

93. John Ely, for example, has terrible trouble using his theory to distinguish the result in Griswold v. Connecticut, 381 U.S. 479 (1965), of which he approves, from that in Roe v. Wade, 410 U.S. 113 (1973), with which he disagrees. See Ely, The Wages of Crying Wolf: A Comment on Roe v. Wade, 82 YALE. L.J. 920, 929-32 (1973); J. ELY, supra note 3, at 219 n.118 \& 221 n.4. 
controversial among political scientists and other observers of the American scene. Perhaps the people really do rule, but a reasonable case can be made that they do not. ${ }^{94}$ The natural response is, "Sure, but constitutional adjudication can be aimed at making certain that the people rule," a proposal crafted into its most persuasive form by John Hart Ely. ${ }^{95}$ Unfortunately, even that admirable goal does not arise unambiguously from the constitutional text itself. Thus the second obstacle: The decision to pursue that goal is susceptible to the charge of arbitrariness, because it seems to be more a preference of its proponents than a command of the Constitution. ${ }^{98}$

Another response to the charge of inherent contradiction is to try to circumvent it. Because of the general acceptance of the rule of law, shouldn't the institutions of government in general, and the courts in particular, act as though they are working in accordance with law, as a means of preserving what we call the fabric of society? Put more bluntly, shouldn't we all shut up and continue to pretend that there exists somewhere a proof (acceptable to the relevant interpretive community) that the Constitution really does grant courts the final authority to interpret its provisions and that those interpretations are in accordance with widely accepted rules and may thus be termed correct?

The best answer may be a reluctant "no." Choosing to escape the dilemma through disingenuousness places the constitutional theorist on dangerous ground. By conceding even the possibility that pretense might be necessary to maintain the rule of law, the theorist falls right back into the delegitimizing trap. Admitting that government under the Constitution might not be able to function-indeed, that it might not survive-unless political actors and constitutional theorists prevaricate, merely demonstrates that the interpretive community's claim that it knows the meaning of the sacred text is a sham. When a government can maintain its authority only by lying about the basis for that authority, then revolution might indeed be the only morally justifiable path.

To return to the metaphor of Sisyphus, revolution would mean, I suppose, walking away, letting the boulder roll down the hill, and daring the gods to do their worst. But before concluding that the path of revolution is

94. See, e.g., T. Lowi, The End of Liberalism (2d ed. 1979); R. Wolff, The Poverty of LIBERALISM (1968). When in a sufficiently somber mood, I find myself among the doubters. For an example of what too much introspection can bring about, see Carter, Technology, Democracy, and the Manipulation of Consent (Book Review), 93 YAL.E L.J. 581 (1984).

95. See J. ELY, supra note 3, at 73-134.

96. See, e.g., Brest, supra note 57; Laycock, Taking Constitutions Seriously: A Theory of Judicial Review (Book Review), 59 TEx. L. REv. 343, 356-60 (1981). 
the only one available, it might prove useful to take the time to study the mountain from a slightly different angle.

\section{Our Political Constitution}

None of the conventional approaches, then, seems fully adequate to resolve the fundamental questions raised by the delegitimizing critique of constitutional theory. ${ }^{97}$ The problem, all agree, is constitutional adjudication based on a text charitably described as indeterminate. The only solution, according to conventional constitutional theorists and delegitimizers alike, is the identification of interpretive rules that enable a reader to give meaning to the text without significant reference to the reader's own values.

The preferred approach, which I have called the perfectionist response, is, I would suggest, too narrow. It concedes far more than it must to the critics; it responds to only a part of the genius of Alexander Bickel's ideas; and it ignores the wisdom of Justice Walker's critique of the search for perfection. Equally important, the perfectionist response struggles against, rather than making the most of, the assertions by delegitimizers of the ultimate inseparability of law and politics. Searching for the "best" interpretive rules is obviously important, but a successful search is indispensable to judicial legitimacy only if one believes that neutrally construing the constitutional text is the sum total of governance. ${ }^{88}$ If the Constitution does no more than set forth a framework for legal analysis-if it is, in short, a legal document in the conventional sense, one that the legally trained are best able to construe-and if the interpretations placed on the Constitution by the courts serve as the true governing force of society, then determining the rules for interpreting it is a legal task and the only way out of the delegitimizing dilemma. But the Constitution, as I argued earlier, ${ }^{89}$ performs a political as well as a legal task. The Constitution establishes more than a system of legal relationships to be resolved by a Supreme Court of the United States; it also sets up a system of political relationships to be resolved through the government of the United States.

This distinction matters. The conventional constitutional theorists and their delegitimizing critics write as though the Court's decisions about the

97. Of course, this also works the other way around: The delegitimizing critique does not answer the questions posed by conventional theorists. Delegitimizers are aware of this symmetry, and Professor Tushnet, for one, seems quite proud of it. See Tushnet, Critical Legal Studies, supra note 8, at 626-27.

98. The justification for this point will become clear presently. At this juncture I would note only that there is a distinction between adjudicating a dispute-something that arbitrators and elementary school teachers do just as much as courts do-and running a country, which is the province of the very few.

99. See supra text accompanying note 54 . 
meaning of the indeterminate portions of the text represent the salient challenges to that cherished liberal ideal, the rule of law. ${ }^{100}$ For two reasons, I would suggest that that assumption is not so clear. First, the cries of doomsayers notwithstanding, the nation is not governed solely or even primarily by the Gourt's pronouncements on fundamental rights. The fundamental rights decisions, although undeniably important, arguably play a relatively small role in the day-to-day affairs of the nation and a far smaller one in the broad sweep of history. ${ }^{101}$ Should that first argument prove ultimately unconvincing, a second, more forceful argument, is available. The constitutional provisions establishing the government structure in general, and the system of checks and balances in particular-the provisions of what might be called "our political Constitution"102_often speak with a clarity not found in the less determinate provisions. The relatively more determinate clauses of this political Constitution generally play by far the more important role in determining how the nation is governed, and thus create a structure within which judicial activity can be cabined. Taken together, these twin understandings represent a first step toward reconstructing constitutional theory from a different perspective, one that avoids much of the force of the delegitimizing critique, but that nevertheless is suggested by the document itself. This different perspective focuses on justifying the process of judicial review by considering its place in a broader governmental scheme rather than on justifying the particular results reached in any given case. In the end, this fresh perspective might strike the reader as a mere muddle, but as I shall presently argue, a muddling and illegitimacy are not necessarily the same.

100. Cf. Monaghan, Our Perfect Constitution, 56 N.Y.U. L. Rev. 353 (1981) (disputing claims that Constitution guarantees everything that is morally correct).

101. Mark Tushnet has made a similar point. See Tushnet, Following the Rules, supra note 8, at 788-89 \& n.19.

102. As my student Jefferey Sellers has pointed out, "political Constitution" may not be the ideal nomenclature, because it impliedly includes provisions guarding purely political rights-provisions I do not mean my comments to cover. When I say "political Constitution," I mean the Constitution of political institutions, of formal checks and balances, and not the Constitution of individual rights.

What I call the political Constitution, Alexander Bickel labeled, with a bit more analytical flavor but a certain loss in precision, a part of "the manifest constitution" as against "the constitution of open structure." See A. Bickel, MORALITY, supra note 82, at 29. The manifest constitution he defined as "the constitution of the mechanics of institutional arrangements and of the political process, of power allocation and the division of powers." Id. He also included what I would omit: "the historically defined hard core of procedural provisions, found chiefly in the Bill of Rights." Id. To Bickel, the manifest constitution imposed on public officials a duty to obey: "To deny this idea is in the most fundamental sense to deny the idea of law itself." Id. at 30 . I would agree with this last comment, adding the observation that the comment is rendered sensible only if there is indeed a relatively determinate provision-a provision of what I would call the political Constitution-that the official upon whom the duty devolves is able to comprehend without the necessity for resort to the judicial process. 


\section{A. Fundamental Rights and the Indeterminate Text}

Ever since Learned Hand announced that he would not want to be governed by a bevy of Platonic guardians, ${ }^{103}$ critics of the Supreme Court have contended that unless we rein in the Justices, we will be governed by something much like that. ${ }^{104}$ In general, these critics have attacked those decisions loosely grouped together as protecting "fundamental rights."105 The fundamental rights decisions are said to be without guiding standards traceable to any provision of the Constitution and hence lawless-unless one believes that the Constitution should indeed be read to constitute the members of the Court as the dictators of morality.

Well, maybe. Certainly there are serious analytical problems with some of the Court's fundamental rights decisions. And several of the decisions have announced results that many people of good will find morally reprehensible. ${ }^{108}$ All the same, it is worth examining the fundamental rights decisions a bit more closely to determine whether-even if objective standards of measurement exist and all the cases in question are either wrongly decided or simply lawless-the nation can properly be said to suffer from government by judiciary.

In the last decade, most of the shouting about standards for judicial decision has seemed to revolve around the Court's treatment of the abortion issue in Roe v. Wade $e^{107}$ and subsequent decisions. ${ }^{108}$ To be sure, however, the shouts in earlier decades about Baker v. Carr, ${ }^{109}$ Brown v. Board of Education, ${ }^{110}$ Schechter Poultry Corp. v. United States, ${ }^{111}$ Lochner v. New York, ${ }^{112}$ Dred Scott v. Sandford, ${ }^{113}$ and even Marbury v.

103. See L. HAND, The Bill of Righrs 73 (1958): "For myself it would be most irksome to be ruled by a bevy of Platonic Guardians, even if I knew how to choose them, which I assuredly do not."

104. A. Bickel, The Supreme Court and the Idea of Progress 173-81 (1970); Berger, Paul Brest's Brief for an Imperial Judiciary, 40 MD. L. REv. 1 (1981).

105. This grouping includes cases decided under such diverse constitutional provisions as the equal protection clause, the due process clause, the First Amendment, and the Eighth Amendment, and various combinations of these and other provisions.

106. See Cover, The Supreme Court, 1982 Term-Foreword: Nomos and Narrative, 97 HARv. L. REv. 4, 7 (1983) (footnotes omitted): "It is a somber fact of our own world that many citizens believe that, with Roe $v$. Wade, the Supreme Court licensed the killing of absolutely innocent human beings. Others believe that the retreat from Furman $v$. Georgia has initiated a period of official state murder."

107. 410 U.S. 113 (1973).

108. See, e.g., City of Akron v. Akron Center for Reproductive Health, Inc., 462 U.S. 416 (1983); Bellotti v. Baird, 443 U.S. 622 (1979); Planned Parenthood of Mo. v. Danforth, 428 U.S. 52 (1976). To be sure, the subsequent decisions cut both ways. See, e.g., H.L. v. Matheson, 450 U.S. 398 (1981); Harris v. McRae, 448 U.S. 297 (1980); Maher v. Roe, 432 U.S. 464 (1977). But the abortion issue is one sufficiently divisive that decisions in either direction provoke considerable controversy.

109. 369 U.S. 186 (1962).

110. 347 U.S. 483 (1954).

111. 295 U.S. 495 (1935).

112. 198 U.S. 45 (1905).

113. 60 U.S. (19 How.) 393 (1857). 
Madison, ${ }^{114}$ might have had some of the same tenor. "By what right are courts doing what they are doing?" the critics demand. The criticism can be broken down further into two strands: challenges to the institution of judicial review and challenges to the substantive correctness of the decisions in question. Most of the recent criticism (outside of the delegitimizing movement, to which I will shortly return) has been of the second type. For these mainstream critics, the problem is not that the courts have decided these cases, but that they have decided them incorrectly. ${ }^{115}$ To some extent, the complaint that Roe $v$. Wade is wrongly decided may be viewed as an assault on the legitimacy of one form of judicial review-the form that finds fundamental rights in constitutional language that might charitably be called imprecise-but few mainstream critics seriously assert that the Justices lack the power to render constitutional judgments. ${ }^{116}$ Thus it is fair to treat even this more refined form of argument as a contention that particular cases are wrongly decided.

That form of criticism is fine as far as it goes, but a colorable case can be made that with the possible exception of Baker $v$. Carr, which may be a special case, ${ }^{112}$ none of the Court's fundamental rights decisions has worked a societal change so fundamental and revolutionary that it could not in fairly short order have been brought by other means. I am not here suggesting that the decisions are unimportant but rather resisting the notion that social change has come about solely because the Supreme Court has decreed it. The Court might play a vital role in the process of moral evolution, but in the end, law is not effective unless the nation changes itself. Thus Brown might have roused a nation's conscience to an understanding of the evils of segregation, but the nation was already moving, albeit in its agonizingly slow and clumsy fashion, toward a recognition of the horrors of the practice. Dred Scott might have heightened the nation's divisions over slavery, but the divisions were there in any event, and it is a gross exaggeration to contend that the decision "caused" the Civil War. Roe might have sparked a nationwide debate on the issue of abortion, but

114. 5 U.S. (1 Cranch) 137 (1803).

115. See Laycock, supra note 96 , at 349 (distinguishing between arguments that cases are wrongly decided and arguments that they are improperly in court).

116. Although the abortion cases have in recent years been the major focus of controversy, the focus is in some ways a peculiar one. Even were Roe reversed, abortion might not be outlawed; as Professor Tushnet has pointed out, abortion rights in some form enjoy considerable political support, as evidenced by the post-Roe actions of state legislatures. See Tushnet, Following the Rules, supra note 8 , at 788 n.19.

117. The Court in Baker permitted a suit aimed at altering the way in which public officials were elected. Baker is unusual, as John Ely has pointed out, because, once obeyed, it could not be overturned by political means: "[T]he incentive of elected representatives is not necessarily toward malapportionment, but rather toward maintaining whatever appointment, good or bad, it is that got and keeps them where they are." J. ELY, supra note 3, at 121. 
the debate, which has yet to settle into consensus, would surely have continued no matter which way the case was decided. Obviously, in each case American history would have been different-perhaps briefly-had the decision gone the other way, but it is difficult to resist the conclusion that the ultimate resolution of each controversy was or will be the result of public dialogue and political decision. ${ }^{118}$

If true, the conclusion that we as a nation are not really governed by the Supreme Court's fundamental rights opinions cuts against the force of one part of what the delegitimizers have to say. Their assault on constitutional legitimacy relies in part on the asserted lawlessness of these opinions. But even if the opinions can be simultaneously arbitrary and consistently supportive of the existing order-a proposition not at all selfevident ${ }^{119}$ - the problem takes on importance only in proportion to the degree of governance that the opinions reflect. The fundamental rights opinions arguably reflect relatively little governance. Some things may happen a little sooner or a little later than they would otherwise happen, but changes of that sort represent less governance than fine-tuning.

In this sense, the constitutional court is to the society it serves as an outside auditor is to a corporation. The corporation makes policy and the outside auditor makes findings that can ultimately cause the corporation to reverse its policy, but a sufficiently determined corporation will in the end do what it wants. Similarly, a court may try to guide policy choices, but only rarely can initiate new policies. Relatively few judicial decisions cannot be circumvented by a sufficiently clever legislature or an adequately aroused populace; that more decisions are not overturned simply

118. Possibly this conclusion only sharpens the point made by one group of delegitimizers. To them, the process of constitutional adjudication is informed by and also a constituent of the larger social order. What we call the rule of law is influenced by, dependent on, and supportive of, this same existing order. Naturally the judges "go along with the program." That is, according to these critics, precisely what the law of the liberal state is for. The opposite conclusion-that the courts really issue powerful and troubling challenges to the status quo-would come as something of a shock to the delegitimizing critic from this school. See Kennedy, Structure of Blackstone, supra note 16; Tushnet, Critical Legal Studies, supra note 8.

Even if this school of thought is correct, its central thesis may be less important than its adherents make it appear if, as I here suggest, the fundamental rights decisions are not central to the nation's governance. The dissenting critic may consider this point ultimately circular, but the critic cannot have it both ways. If the fundamental rights decisions play little role in governance, then a challenge to their validity should hardly shake the foundations of liberal constitutionalism. If on the other hand the decisions command tremendous and sweeping societal changes, then it is difficult to see how they can be masks for perpetuation of the existing social order.

119. After all, if the law is truly constituent of and supportive of the existing order, then it ought not require any twisting of doctrine for the law to be read in a way that supports the existing order. If on the other hand the law that supports the existing order seems to be badly mangled and inconsistent, the reason can only be that it is being compared with something else, some other law that is to the contrary and thus is necessarily opposed to the existing order. But see Taylor, Deconstructing the Law (Book Review), 1 Y ALE L. \& PoL'x REv. 158, 161 n.16 (1982) (explaining why "[n]o necessary contradiction exists between the realist position that the law has no autonomous, formal logic and the Marxian position that the law serves the needs of capital in a highly logical manner"). 
indicates that public opinion that a case is wrongly decided does not translate automatically into public determination to change it-as many politicians have learned to their frustration. Other decisions may survive because, quite simply, the public changes its collective mind. When public opinion shifts to accept a once-controversial judgment, the people, not the courts, are nevertheless governing. In controversies of this sort, the courts may play what some theorists have termed an "educational" role: By holding up to stark scrutiny societal practices they consider pernicious, the Justices may propel otherwise indifferent citizens to the conscious decision whether to continue or abandon the practices. Thus, whether the controversial decision is obeyed, evaded, or overturned, the ultimate decision rests with all political actors, not merely with the judicial ones. Even the few decisions that cannot easily be circumvented pass eventually either into the national conscience, as perhaps Brown has, or into history, in the way that Schechter Poultry (not yet overruled) has surely done. ${ }^{120}$

This is not to deny the importance of the Supreme Court's fundamental rights decisions or to suggest that the search for a principled theory to explain how they should be made is really much ado about nothing. The need for a theory to explain these particular cases, should not, however, be overestimated. Courts account for a good deal of governance, but they hardly account for most of it: The most self-consciously activist judge can only react to what other governors propose and can react only in a way that the other governors will ultimately approve. ${ }^{121}$ True, those other governors must have judicial approval for their actions too, but that only demonstrates what every schoolchild supposedly learns: The constitutional system provides for checks and balances. The text, moreover, is relatively clear on the existence of these checks and balances, however fuzzy it might be on their day-to-day operation. ${ }^{122}$

120. I am not prepared to speculate here on what sacial and historical forces might be at work in the determination of whether a controversial decision passes into the national conscience or into history. I only suggest that they are not different from the historical forces that generally help motivate the mechanisms of popular change and consent. A critique of those forces is thus a critique of liberalism as an ideology, and is irrelevant to an argument that constitutional adjudication is inconsistent with the tenets of liberalism.

121. I do not mean to suggest here that judges are entirely bounded by their readings of the text of public opinion. So firm a position would run counter to the direction in which this essay points. On the other hand, no matter how unlikely official defiance of the courts may be, no judicial decision can possibly pass into the national conscience unless the political governors ultimately approve it. I doubt that the delegitimizers would disagree with this proposition, for if the law is truly indeterminate, if enforcement of law (as they contend) is a matter of politics, then no other conclusion is sensible. See A. BiCKel, Morality, supra note 82 , at 91-123.

122. Although I recognize that the move is a controversial one, I would include judicial review as a check with respect to the existence of which the text is relatively clear. I find myself convinced by Professor Wechsler's argument that there is no other way of harmonizing Article III's broad grant of a judicial power ("all Cases") with the command of Article VI that the Constitution be the supreme law of the land. See Wechsler, supra note 15. 


\section{B. Checks and Balances and the Determinate Text}

If important parts of the constitutional text are truly indeterminate-if there really is no authoritative interpretive community capable of agreeing and willing to agree on the standards for review or the means of their application-then this system of checks and balances is of crucial importance. After all, not every provision of the Constitution is indeterminate. Some theorists have argued that all provisions of the document should be equally open (or closed) to interpretation, ${ }^{123}$ but it seems idle indeed to argue at length over whether the document speaks clearly when it permits two-thirds of the Congress to overrule the President's veto ${ }^{124}$ or restricts membership in the House of Representatives to those who have attained the age of twenty-five. ${ }^{125}$ Some theorists have tried to use the more determinate clauses of the Constitution to pour substantive content into the less determinate ones. ${ }^{128}$ In the pages to follow, I suggest instead using the more determinate provisions to justify the process of interpreting the less determinate ones. This justification does not turn in any way on whether any particular fundamental rights decision is guided by standards traceable to the Constitution in a manner not contingent on the interpreter's values. Those who find unpalatable the assertion that the fundamental rights decisions represent only a small component of governance may find this alternative argument somewhat easier to digest.

\section{The Political Constitution}

First-year law students have less trouble working out the system of checks and balances than they do mastering the vagaries of substantive due process, and the reason is obvious: With respect to the structure of government, those who drafted the Constitution were at pains to be as precise as they could; with respect to the rights of the people, on the other hand, they left considerable room to maneuver. This approach makes sense if one accepts the received wisdom (which there seems little reason to doubt) that the Framers accepted as axiomatic the twin propositions that the role and powers of government should be limited and that the scope of individual rights should be broad. ${ }^{127}$

Those who wrote the Constitution plainly understood this distinction.

123. See, e.g., Brest, The Misconceived Quest for the Original Understanding, 60 B.U.L. Rev 204, 237-38 n.124 (1980); Saphire, The Search for Legitimacy in Constitutional Theory: What Price Purity?, 42 Oнiо ST. L.J. 335, 337-38 (1981).

124. See U.S. ConST. art. I, \$ 7, cl. 3 .

125. See id., art. I, § 2, cl. 2.

126. See, e.g., Laycock, supra note 96 , at 354-56.

127. See, e.g., G. WoOd, The Creation of the AMERican Republic, 1776-1787, at 471-564 (1969); Grey, Origins of the Unwritten Constitution: Fundamental Law in American Revolutionary Thought, 30 Stan. L. Rev. 843 (1978). 
So, for example, although the drafters expressed the concern that political leaders must be "mature," their chosen method for guaranteeing maturity was not to use the possibly vague word itself, but rather to write specific age limits into the document. ${ }^{128}$ Similarly, rather than providing that the President's veto can be overturned by "an extraordinary majority" of Congress-which must surely be what they intended-the Framers fixed an explicit floor on the necessary majority. ${ }^{129}$ The specificity of these clauses is completely sensible if the authors were attempting to implement a particular conception of the way the government should work. Thus while we assume with respect to the entire Constitution that the Framers meant what they said, we may also assume that with respect to the Constitution's structural provisions they took care to say what they meant. The entire Constitution means something; the more determinate clauses mean something specific. After all, these structural provisions were meant to constitute a government comprising institutions that would interact, and it is difficult to design institutional interaction without a concrete image of what the institutions are. Because the structural provisions are relatively clear, moreover, important substantive biases held by the interpreters -the judges-cannot easily creep in and corrupt the process of adjudication. ${ }^{130}$

When I say "relatively clear," I am obviously hedging, but only a little bit. Some of the details of the structural provisions are obscure-what is meant, for example, by an "adjournment" of Congress which makes it impossible for the President to return a bill, thus giving rise to his pocket veto power ${ }^{131}$-but they are possessed of the sort of obscurity that raises few analytical difficulties. Few members of the legal community or of the general community would struggle long against the notion that with respect to language of that kind the authors clearly had in mind some specific institutional design, and the interpretive task is simply to discover what it was that they meant. To be sure, not even the political Constitution speaks with crystal clarity, but its more determinate clauses come reasonably close, and compared with the language of, say, the Eighth Amendment, the pocket veto provision is a model of articulation and detail.

This distinction may provide the basis for a reasoned response to what

128. For a more detailed discussion of this admittedly obscure bit of history, see Carter, Judicial Power, supra note 56, at 1358 \& n.76.

129. See U.S. ConST. art. I, § 7, cl. 3.

130. Obviously, the biases embodied in the structure itself will creep in, but that is a separate and for present purposes irrelevant criticism. See infra p. 857.

131. See U.S. CoNST. art. I, $\S 7, \mathrm{cl} .2$ (pocket veto provision), interpreted in The Pocket Veto Case, 279 U.S. 655 (1929); Wright v. United States, 302 U.S. 583 (1938). 
the delegitimizers have to say. The more determinate clauses of the political Constitution may provide a comprehensible structure within which adjudication that requires judicial interpretation is a legitimate activity. Despite the difficulty in finding clear rules for interpreting the less determinate clauses protecting fundamental rights, it ought to be possible to develop clear and straightforward rules for interpreting the more determinate ones constituting the structure of government. The idea that this distinction has hermeneutical significance is basically an old one and needs only fresh elucidation in the face of the contemporary assault on conventional constitutional theory. For if the idea is correct, then despite the scholarly battles over the meaning of the Constitution's less determinate or indeterminate provisions protecting individual rights, the delegitimizers need not carry the day. If the meaning of the more determinate provisions can be worked out in accordance with a process leaving little room for value choices by the interpreters, then even if the process sometimes seems tedious, it should nevertheless provide results that are sufficiently certain to begin to legitimate the system.

\section{A Rule for Interpretation}

When deciding cases arising under the clauses of the political Constitution, the courts are doing something quite different from what they do when deciding cases involving claims of individual rights. They are intervening in a process that only rarely demands their intervention. After all, the federal government functions from day to day-and from decade to decade-without relying on the courts for instruction. Every four years a President is elected, and every two years the entire House of Representatives and one-third of the Senate must face the voters. No adjudication is thought to be necessary to figure out how we know who the President is, how the President appoints members of his staff, how they are paid, how congressional offices are to be allocated, who will sit on which congressional committees, and so on. On the contrary: The great majority of dayto-day activities of the federal government continue without the need to pause and await authoritative judicial construction of the constitutional text. $^{132}$

Working within this well-understood structure, moreover, the President and other political actors are able to create and dispense the primary manufactured product of all modern government enterprise, policy. The

132. Admittedly, the analysis I present here might be different had the courts never developed the political question doctrine. That doctrine, however, may be no more than a name given to the judicial acknowledgement of the reality I describe in this section of the Article. See Henkin, Is There a "Political Question" Doctrine?, 85 YALE L.J. 597 (1976). Not all provisions of the Constitution and not all real-life intra-governmental conflicts either require or permit judicial interpretation. 
vast majority of policies adopted by the government are either never subjected to judicial scrutiny or routinely approved in the face of essentially frivolous court challenges. This does not mean that the government is lawless; it does mean that the courts do not do everything, or even many things, necessary for governance. The United States is governed instead by its political governors, chosen in accordance with the relatively clear constitutional scheme.

The system of checks and balances, which forms a vital if often overlooked part of the constitutional scheme, also functions for the most part without resort to the courts. Important components of the system are wellknown: The President can veto legislation, but Congress can override the veto; no federal money may be spent without congressional consent; the judges of the federal courts are nominated by the President and confirmed by the Senate; Congress can impeach and remove from office any government official; and on and on.

This system of checks and balances is the tool that the Framers expected the nation would use to avoid or control any dangerous concentrations or arbitrary usurpations of authority. Thus, the Framers would not have believed that their Constitution permitted rule by a bevy of Platonic guardians, because they wrote into the document safeguards against exactly that hazard. Yet the essence of the delegitimizing attack on the institution of judicial review is that constitutional adjudication, if it is ultimately standardless, is precisely the arbitrary usurpation against which the Framers thought they were guarding.

The fact that the government continues to operate suggests two important notions: first, that lay readers are capable of construing and applying in practice many provisions of the Constitution, and, second, that this historical practice has provided authoritative constructions of most of the provisions relating to the structure of government. ${ }^{133}$ In this sense, the "meaning" of many of the more determinate clauses of the political Constitution is imposed externally, by what actually happens, rather than internally, through adjudication and judicial interpretation. ${ }^{134}$ This too is a process of law formation, and its apparent standardlessness should matter only to those who reject the proposition that we have even in part a political Constitution. The ability of the political Constitution to take on some of its meaning from historical practice is not a flaw in the system, but an

133. Naturally, the lay readers are sometimes following venerable judicial precedents. With respect to the functioning of government, however, that is far from the usual case. Where it is the case, moreover, what matters most is that the precedents be cases decided in accordance with the rule suggested here.

134. Among the better-known elucidations of this point are the Supreme Court's in United States v. Midwest Oil Co., 236 U.S. 459, 474 (1915), and Justice Frankfurter's in his separate opinion in Youngstown Sheet \& Tube Co. v. Sawyer, 343 U.S. 579, 610-11 (1952) (concurring opinion). 
advantage, for it enables the government to function and to govern-and to do so without constant resort to the judiciary. It may of course be the case that there are sets of interpretive rules under which many of these historically accepted constructions would be incorrect, ${ }^{135}$ but that objection is less impressive than is the simple conclusion that the government continues to operate. A consistent historical practice does not of course by itself establish a constitutional rule. ${ }^{136}$ The political Constitution, with its relatively determinate clauses, still limits the processes through which the government can transform values into policy. But working out the meaning of these clauses should be, as I have said, a reasonably straightforward task; far more important, in all but a tiny number of instances, the government will continue to function from day to day without transgressing the limits.

These day-to-day operations might easily be ridiculed as no more than a muddle, and there is a degree of truth to that description. But the degree of truth is a comfortable one; to say that the government muddles is not at all the same as saying that the government is lawless. Muddles, as Arthur Leff pointed out, come in more than one shape. ${ }^{137}$ In general, the muddling has nothing to do with constitutional interpretation. The system of checks and balances prescribed by the political Constitution creates a reasonably clear framework within which the muddling can be contained. More important, since the purpose of the rules of interpretation for the more determinate provisions-those constituting the government-ought by now to be clear, the courts can correct the muddling when it moves too far off course. The correction, moreover, is in accordance with standards that the judges can comprehend easily and apply consistently. One might object, of course, that the political Constitution itself incorporates value preferences, but that is altogether a separate argument. Conventional theorists readily concede, as they should, that there are values that the Constitution holds dear, even if they cannot agree on which values these are. Judges may fairly be criticized for many things, but imposing the value choices already made in the Constitution is not among them-not, at least, when the question in issue is whether the judges are imposing values of their own. When imposing the choices made in the Constitution, judges

135. An instructive disagreement over the significance of the historical sources on a question regarding interpretation of the political Constitution is that between the majority and the dissenters in Nixon v. Fitzgerald, 457 U.S. 731 (1982). For an analysis, see Carter, Judicial Power, supra note 56, at 1357-67.

136. See Black, The Working Balance of the American Political Departments, 1 Hastings Const. L.Q. 13, 20 (1974); Carter, The Constitutionality of the War Powers Resolution, 70 VA. L. Rev. 101, 121-26 (1984) [hereinafter cited as Carter, War Powers].

137. See Leff, supra note 2 . 
are merely acting in conformance with the liberal ideal of a knowable, enforceable law. ${ }^{138}$

The question, then, is whether the law created by the more determinate clauses of the political Constitution is in fact knowable. The answer is a tentative "Yes." The sharpest debates in conventional theory concern the meaning of the less determinate clauses protecting individual rights. But to debate their meaning is, in a very real sense, to miss the point. The due process clause does not have a meaning in the same way that the presentment clause has one. The presentment clause embodies a concrete conception of the way that a particular government process is to work; the due process clause states a very vague and very general value preference.

This much is common ground among most constitutional theorists. The difficulties arise when one seeks to figure out whether the distinction is significant. Yet the significance ought to be clear: The process of formulating interpretive rules is quite different in the two cases. The main disagreement over rules for interpreting the Constitution's less determinate clauses stems from an underlying disagreement over what those rules are for. To borrow from Ronald Dworkin, the disagreement is over whether the rules should implement the Framers' broad concepts of constitutional meaning or their narrow conceptions of the same. ${ }^{38}$ Thus, what really separates a Raoul Berger from a Michael Perry is not their disagreement over the rules, but their disagreement over what the rules are supposed to do. Where one believes that interpretive rules have no purpose other than the implementation of a concrete conception of the author, ${ }^{140}$ the other considers the function of the rules to be the enabling of an evolutionary process through which the broad concepts take on fresh meaning. ${ }^{141}$ This disagreement is easy to understand, for when the language of a clause is so general that the authors must have been stating a broad concept rather

138. Self-conscious reference to natural law might tell us when following the mandate is itself immoral. When the judge is forced to choose between loyalty to mandate and to higher law, not prescribed by the sovereign, the liberal ideal breaks down. John Ely has argued that the judge who finds herself forced to choose between mandate and natural law, if she chooses the latter, should explicitly recognize that she is engaged in civil disobedience. See J. ELY, supra note 3, at 182-83. This choice may indeed represent civil disobedience, unless a connection can be shown between higher law and the judicial function in the liberal state. See infra p. 861 \& note 149 . Recent ambitious attempts to draw the connection include B. ACKERMAN, Social JUSTICE IN THE LibERAL STAtE (1980); R. Dworkin, Taking Rights Seriously (1977); and J. Rawls, A Theory of Justice (1971).

139. See R. Dworkin, supra note 138, at 134-36. For Professor Dworkin's later, more detailed elucidation of this distinction, see Dworkin, The Forum of Principle, 56 N.Y.U. L. REV. 469, 471500 (1981). In the later article, Professor Dworkin is careful to disavow support for a proposition ascribed to him by some critics: that the interpreter should care whether the Framers intended that their views should be a guide. See id. at 495-97. Like Professor Dworkin, I do not rest my argument concerning the weight to be given the Framers' views on the weight they intended their views to have.

140. See R. BERGER, supra note 3 .

141. See M. PERRY, supra note 3. 
than a specific conception, it is not easy to determine the purposes to be served by interpretive rules. And when there is no agreement on the purposes of the rules, agreement on the rules themselves is virtually impossible.

When, however, the language or structure of a clause makes plain that its authors had in mind a specific conception, the purpose of the interpretive rules is plain. In that case, the task of the theorist is to discover precisely what that something was. Thus, for all the difficulty in discovering interpretive rules for the Constitution's less determinate clauses, the rules for interpreting the more determinate clauses should be easy to understand, and the process of interpretation should be straightforward. The purpose of the rules for interpreting the more determinate clauses of the political Constitution ought to be to discover the objectives of the drafter. Rules that aid in that task should be preserved; rules that hinder it should be discarded.

\section{The Dilemma of Originalism}

Among some conventional theorists, it is fashionable and probably sensible to view with suspicion calls for discovery and enforcement of an original understanding. ${ }^{142}$ Insistence on harking back to the views of the Framers is frequently seen as a means for attaining particular results-quite often unattractive ones-according to the dictates of ideology. ${ }^{143}$ Sometimes this is undoubtedly the case. Searches for the original understanding, moreover, present problems even apart from the possibility that the results obtained will, from a self-conscious natural law perspective, seem morally repugnant. One obvious problem is hermeneutical: Can we know the thoughts of the Framers at all ? ${ }^{144}$ Possibly we cannot, but as

142. See, e.g., Brest, supra note 123; Munzer \& Nickel, Does the Constitution Mean What It Always Meant?, 77 Colum. L. Rev. 1029 (1977).

143. Cf. Kelly, Clio and the Court: An Illicit Love Affair, 1965 SuP. CT. Rev. 119 (accusing Supreme Court Justices of manipulating history to reach results they prefer).

144. For an argument that notions of legislative intent or original understanding cannot rescue an indeterminate text, see Moore, The Semantics of Judging, 54 S. CaL. L. Rev. 151, 256-70 (1981). I have suggested elsewhere that in constitutional analysis, the proper search is not for some too-narrow objective, or for unanimity of any sort, but rather for "a common understanding reflected in the shared views of an overwhelming majority." See Carter, Judicial Power, supra note 56, at 1360 n.82. The search should aim to determine what effect was generally expected, not what the authors planned. The hope should be to demonstrate a consensus in the face of which "the mere existence of a handful of contemporaneous statements arguably to the contrary does not defeat the notion that a consensus existed, as long as the primary evidence is concrete and powerful." Id. I would, in other words, draw an important distinction between an "intent" and an "understanding." As a rule, the former will be harder to demonstrate than will the latter, but with respect to the Constitution's more determinate provisions, the more general understanding should be adequate to provide an enforceable meaning. I would not purport to apply any test of this kind to the less determinate clauses, and in any case I am not convinced that identifying a consensus would suffice to refute Professor Moore's interesting argument on the interpretation of indeterminate language. I do not, however, advocate use of 
even Professor Tushnet has admitted, the mere fact that working out the authors' conception might present hermeneutical difficulties hardly indicates that the authors had no conception. ${ }^{\mathbf{1 4 5}}$ If the authors indeed had in mind a specific conception, then trying to find it in order to assign a "meaning" to the language in question makes considerable sense.

A more troubling presentation of the modern assault on originalism as a method of constitutional understanding has rested largely on the conviction that sharp discontinuities exist between the world the Framers knew and the world we now inhabit and in which we must apply the provisions of the Constitution. Paul Brest has argued, for example, that it makes little sense to ask how the Framers intended the Eighth Amendment's prohibition on cruel and unusual punishment to be understood. ${ }^{146}$ Given that their world and ours are so utterly foreign to one another, he argues, not even the words they chose maintain the same meaning. The drafters understood every word of that and other provisions to carry a significance unique to the world in which the writing took place; trying to give the words the same significance in our wholly different world is a hopeless task.

This point has force with respect to the entire panoply of provisions protecting individual rights. The provisions were drafted by leaders who saw government oppression as a real possibility in their own lives. It would be remarkable to think that the words could possibly retain the same significance when those now interpreting them live in a society in which few individuals-and none of the interpreters-see themselves as oppressed. In other words, modern interpreters cannot realistically see the world of the drafters as the drafters themselves saw it. When such sharp discontinuities exist, trying to apply the "original understanding" in the modern world may be a bit like trying to translate the names of colors from a dead language to a living one. You can say you have done it, but you can never be quite sure.

Professor Brest's work differs from most arguments against seeking to import the original understanding because the discontinuities he suggests are so stark. ${ }^{147}$ His analysis may well be entirely correct, but his case is certainly stronger with respect to the Constitution's less determinate clauses than with respect to the more determinate ones. After all, with the exception of the rise of the administrative state-a development that may

originalism as a strategy for adjudicating cases arising under the Constitution's less determinate provisions protecting individual rights.

145. See Tushnet, Following the Rules, supra note 8, at 802 n.59; cf. Tushnet, Darkness on the Edge, supra note 8, at 1041-42 (implying that some constitutional provisions are sufficiently determinate that judges can interpret them without violating principles of liberal adjudication).

146. See Brest, supra note 123, at 220-21.

147. See Gordon, Historicism in Legal Scholarship, 90 Y ALE L.J. 1017, 1020 (1981). 
call for special and creative constitutional analysis beyond the scope of this essay ${ }^{148}$ - the institutions of government that exist today are basically the ones the Framers foresaw. Because the clauses of the political Constitution are relatively determinate, this development is perfectly sensible. Understanding of the manner in which the Framers expected the government to function comes much more easily than an understanding of which rights they expected individuals to retain. Originalism has weaknesses, and with respect to adjudication under less determinate clauses concerned with individual rights, these weaknesses may be fatal. The discontinuities stressed by Professor Brest and others are surely the most glaring of these weaknesses. With respect to the more determinate clauses dealing with the structure of government, however, although the discontinuities may well exist-some surely do-they are not so sharp that seeking the Framers' concrete conception should be rejected as a means for understanding the political Constitution. ${ }^{148}$

Using originalism as a strategy for understanding the political Constitution makes sense for a number of reasons. In the system of checks and balances and the other provisions of the political Constitution, language is used quite often in a fashion plainly indicating that the authors did indeed have a specific conception in mind. Whatever the case with respect to the Constitution's less determinate clauses, moreover, with respect to these structural clauses, neither the moral problem of repugnant result nor the hermeneutical problem of unknowable history should prove insurmountable. In other words, there may be no good reason not to try to discover the original understanding with respect to the provisions of our political Constitution. At the same time, there are strong arguments in support of the attempted discovery. The most important of these is that if judicial decisions aim self-consciously at keeping the structure of government close to the Framers' conception, then with respect to the political Constitution, at least, the courts will be able to claim a relatively value-free rule of interpretation.

At this point, it is important to acknowledge in passing the force of at least one facet of the delegitimizing critique. The delegitimizers are surely correct in their assertion that no act of adjudication-indeed, no act of

148. Cf. Ackerman, Foreword: Law in an Activist State, 92 YALE L.J. 1083 (1983) (calling for new legal analysis in post-New Deal state, because government now initiates societal changes rather than working to preserve status quo).

149. Naturally, to the extent that we attempt to uncover the original understanding, we should be careful not to exacerbate any discontinuities by trying to see the Framers' world through our own eyes. For a more painstaking development of this point, see Clinton, A Mandatory View of Federal Court Jurisdiction: A Guided Quest for the Original Understanding of Article III, 132 U. PA. L. REv. 741, 746-48 n.11 (1984). 
interpretation-can be completely value-free. ${ }^{150}$ But a judge charged with reading and applying a relatively determinate provision of the constitutional text can surely remain vigilant for unconscious influences and strain to avoid conscious influence of wholly personal values. One cannot view any text in the abstract, but the narrower the rule of construction, the less difficult the task of viewing the text as though it were being read in a value-free fashion. Less difficult does not mean easy, and should not even be taken to mean ultimately achievable. A rule of construction guided by the original understanding will, when a concrete conception can be located, render considerably more difficult the task of masking value choices behind legal generalizations. This is but one more reason that I urge that adjudication under the political Constitution be guided by rules of construction that will permit_or require-interpretations that are relatively value-free.

Striving to avoid value-laden rules of interpretation surely matters more when the courts are adjudicating under relatively determinate structural provisions than when they are construing less determinate individual rights provisions. The structural provisions of the political Constitution, after all, say virtually all that the document says (admittedly it isn't much) about the proper role for the judiciary. These structural provisions also set up the system of checks and balances meant to prevent the courts-as well as the other branches-from gaining too much power. Thus, when the Supreme Court decides cases arising under the structural provisions, it may quite often be serving as the judge of its own authority. This happened, for example, in the controversial case of Ex parte McCar$d l e,{ }^{161}$ where the Justices deferred to the authority of another branch, and again in the important case of United States $v$. Nixon, ${ }^{182}$ where they did not. ${ }^{163}$

I have argued elsewhere that the system of checks and balances will survive only if the ability of each of the branches to create what might be called "fresh checks"- checks not apparently contemplated by the system of checks and balances set forth in the Constitution-is sharply curtailed. ${ }^{164}$ Simply by playing their accustomed role, the courts can help keep the legislative and executive branches from indulging the understandable urge to develop fresh checks on the activities of the other branches. But the judiciary, too, is a branch of government, and if the

150. See supra p. 825.

151. 74 U.S. (7 Wall.) 506 (1869).

152. 418 U.S. 683 (1974).

153. I do not of course rest my point on the assumption that either of these cases was rightly decided.

154. See Carter, War Powers, supra note 136, at 112-16; Carter, Judicial Power, supra note 56, at $1364-67,1373-84$. 
system of checks and balances is to succeed, then the courts must also be limited in their ability to create fresh checks. Scrutiny of the judicial branch is particularly important, not only because the courts are usually expected to police themselves, but also because judicial creation of fresh checks can be far more subtle than the creation of fresh checks by the other branches. ${ }^{185}$ The best way to prevent the judicial imposition of too many new checks on the other branches of government is to tie the courts to a narrow rule of construction when they contemplate the relative powers of the branches of the federal government. Viewed this way, application of at least a moderate form of originalism to controversies arising under the structural provisions of the political Constitution may be seen as an instrumental choice: It provides a means of forcing the courts to control themselves, at least with respect to those relatively determinate structural clauses which have language suggesting that their drafters had in mind specific conceptions of institutional design. ${ }^{156}$ In this area more than in any other, the courts should struggle to avoid the charge of the delegitimizers that constitutional adjudication is invariably and necessarily indeterminate.

This analysis, if it is accurate, suggests that interpretation of the Constitution's clauses relating to the system of checks and balances should be straightforward. After all, in establishing the system of balanced and separated powers, the Framers almost invariably had in mind concrete models for the operations of and the relationships among the institutions they were designing. Even the most cursory perusal of the historical record makes plain that the Framers paid far more attention to the clauses regarding the structure of the government than to the fundamental rights provisions that give contemporary theorists so much difficulty. Working out the precise relevance of the original understanding of the structure of government to modern problems will not always be easy, but if limiting the ability of the judiciary to create checks is a sensible notion, then it is that original understanding that should form the basis for interpretation of the Constitution's more determinate clauses.

155. Recognizing the subtlety with which the judiciary can create fresh checks, I have tried to use this theory as a tool to analyze Nixon v. Fitzgerald, 457 U.S. 731 (1982), where the Justices declined to imply a private right of action to pursue damages against Richard Nixon based on his official conduct while serving as President of the United States. See Carter, Judicial Power, supra note 56. I have also argued that there are circumstances in which apparently fresh checks are not really what they appear. See Carter, War Powers, supra note 136, at 116-28.

156. See Carter, Judicial Power, supra note 56, at 1364-67 (explaining instrumentalism of this approach). 
Legal scholars frequently overlook the possibility of distinguishing between the interpretive norms that should be applied to the more determinate clauses delineating government structure and those that might arguably be appropriate for the fundamental rights clauses with meanings that are less clear. Instead they indulge a fallacy that treats construction of all constitutional provisions as part of a single process. Raoul Berger's Government by Judiciary, ${ }^{\mathbf{1 6 7}}$ to take an obvious example, illustrates one half of this fallacy. For Berger, the "original understanding" marks the beginning and the end of constitutional adjudication. That argument may make some degree of sense with respect to a clause with language plainly suggesting that its authors had in mind a particular conception. But the argument simply doesn't work for the vaguely worded clauses concerning individual rights, because their language alone suggests that the authors were writing broadly rather than narrowly.

The other half of the fallacy is illustrated by the general academic disdain for the majority's formalistic analytical approach in Immigration and Naturalization Service v. Chadha, ${ }^{16 s}$ the case in which the Supreme Court struck down at least most forms of the legislative veto. ${ }^{158}$ The Court reasoned from constitutional language, structure, and history, while generally ignoring arguments over public policy. Thus, the majority opinion has been attacked as not being sufficiently forward-looking. ${ }^{160}$ The opinion in Chadha is not beyond criticism, ${ }^{161}$ but an attack of this kind misconceives the nature of adjudication under the political Constitution's more determinate provisions. If they, like the less determinate ones, are subject to the winds of a given day's good and bad ideas, then repulsing the delegitimizing assault will be far more difficult. Some portion of the Constitution must provide a safe harbor from the winds, or, to twist the metaphor a bit, a structure within which the intermittent judicial policymaking can occur and yet be confined. The seemingly intractable difficulties involved in working out general theories of adjudication under the

157. See R. BERGER, supra note 3.

158. 462 U.S. 919 (1983).

159. I have suggested elsewhere that the legislative vetoes contained in the War Powers Resolution might have survived Chadha. See Carter, War Powers, supra note 136, at 129-33.

160. See, e.g., Elliott, INS v. Chadha: The Administrative Constitution, the Constitution, and the Legislative Veto, 1983 Sup. Ct. Rev. 125; Tribe, The Legislative Veto Decision: A Law By Any Other Name?, 21 HARV. J. ON LEGIS. 1 (1984). Incidentally, the Chadha decision has also come in for delegitimizing criticism, suggesting that the delegitimizers will not readily accept the argument that some constitutional provisions are so much more determinate than others that a relatively valuefree rule of interpretation can be claimed. See Spann, Deconstructing the Legislative Veto, 68 MinN. L. REV. 473 (1984).

161. I have elsewhere echoed Justice Rehnquist's view in dissent that the case should have been dismissed on the ground that the plaintiff lacked standing to sue. See Carter, Judicial Power, supra note 56 , at 1391 n.198. 
less determinate clauses suggest that if the harbor exists anywhere, it is in the document's more determinate clauses.

\section{Our Political Constitution, the Functioning Government, and One Reaction to Delegitimation}

Viewed from the perspective that comes once one accepts the notion of a functioning system of checks and balances, the responses that conventional theorists have made to the delegitimizers appear somewhat startling. In challenging the conventional theorists' pretense that the less determinate clauses have a meaning, the delegitimizers offer a tempting gambit. Like all gambits, this one is attractive to the offeree-it certainly looks harmless, at least until it is examined with greater care. All that appears necessary to refute it is a grand theory of constitutional interpretation, and grand theories, after all, are what conventional theorists live for. As all good chess players know, however, a gambit is often best refuted by developing the other pieces on the board. By admitting that the "real issue" is whether they can demonstrate an authoritative interpretation, constitutional theorists have unwisely captured the gambit pawn, when they should instead be developing the rest of their pieces.

The most important pieces that theorists should develop are those that together constitute the system of checks and balances, because it is within that system, if anywhere at all, that the role of the Supreme Court, as interpreter and even policymaker, will be justified, even if the particular mode of operation of the Court-its interpretive norms-will not. It is far less important to find a value-neutral justification for any particular set of norms used by the Justices to interpret the Constitution's less determinate clauses if the very process of generating the norms is considered a part of a functioning, dynamic government system, one in which all policy makers, partly by socialization and partly by design, are constantly checked and balanced. Thus, rather than arguing over the proper interpretive norms for the Constitution's less determinate clauses, those who would counter the delegitimizing assault should be shoring up the wellunderstood and widely accepted interpretive norms for the Constitution's more determinate clauses.

The Constitution's more determinate provisions are often less exciting than such indeterminate provisions as the due process clause and the First Amendment. But the importance of constitutional structure to the legitimization of judicial review can scarcely be denied. It is not the Supreme Court that governs the United States; it is the institutions of the federal government, checking, balancing, and generally interacting with each other, that do so. The key to legitimacy thus is not the construction of any 
particular clause or even the discovery of neutral principles for that construction; rather, the key to legitimacy is a proper understanding of the entire system of checks and balances. Another way of looking at my suggestion is this: The more indeterminate the clauses limiting government power, the greater the need not for rules to interpret these admittedly fuzzy parts of the Constitution, but for rules to interpret the parts that are relatively clear.

To a limited extent, this inquiry may be reduced to the question of whether the system of checks and balances can adequately control the rise of judicial power. If the system cannot do so, then perhaps the delegitimizers have a point, because judicial review is not only standardless, but also unfettered. Thus, one task for those who believe in conventional constitutional theory is to study carefully not merely the interpretive norms that might canalize constitutional adjudication, but all of the various checks and balances that are intended to reduce the chance that the Supreme Court really will evolve into a bevy of Platonic guardians. Scholars have always paid considerable attention to ways of checking the Court, although in recent years, scholarship of this sort has more often been a prop for substantive theories about adjudication under the less determinate clauses than it has been subject of independent examination. ${ }^{162}$ There is a need for much more study of the Court as a part of the complex and working system of checks and balances.

Study of the political Constitution confronts the premise of the delegitimizers: the relation of law and politics. For if the delegitimizers are correct to emphasize this intersection-and it is difficult to see how they could be wrong-then studies of all parts of the government structure become equally important. The source of judicial legitimacy is not merely or mostly the ability of judges to validate their interpretive norms. The rest of the government and the rest of society in effect validate judicial activity by continuing to function. I do not mean to make the rather simplistic argument that the Court's work is fine if nobody objects to it. Rather, I am suggesting that the judicial activity is but one part of a dynamic and interacting and functioning governmental system. And it is that continuing function-the synergistic day-to-day working balance of power-that serves to legitimate the special role played by each of the component parts. ${ }^{163}$ Thus, in considering whether judicial review of the less determinate clauses is legitimate, it may in the long run be as important to debate

162. See supra p. 842. The exception has been the rush to defend the Court from those who would, through affirmative legislation, seek to limit its jurisdiction, see supra note 79 , but it is difficult to resist the feeling that many of the Court's defenders, like most of its attackers, are driven in large measure by concern for protecting particular substantive positions.

163. Although the route $I$ have taken may appear somewhat more roundabout than his, the textual point marks my ultimate agreement with much of what Professor Fiss has to say in the Harvard 
the nature of the war power shared by the President and Congress as it is to understand the intricacies of the due process clause. For without a complete, integrated, functioning, and authoritatively justified system of checks and balances, the delegitimizing argument might prove impossible to refute.

To put the case most plainly, the crying need in efforts to justify conventional constitutional theory may well be for a form of scholarship often ridiculed within the community of legal academics. I refer to what some scholars disdainfully label "doctrinal analysis."164 The particular need is for doctrinal analysis of what I have called our political Constitution. By doctrinal analysis, I mean careful examination of what courts do and should do when faced with questions requiring interpretation of the document's more determinate clauses. I also mean application to the system of checks and balances and other structural provisions of the Constitution of the well-understood interpretive norms, whether based on language, structure, or history, aimed at divining the particular conceptions of their authors, and then the adaptation of those conceptions to contemporary problems. Doctrinal analysis is neither trendy nor instantly impressive; in the face of the delegitimizing effort at constitutional deconstruction, however, it just might be necessary.

Naturally, no matter how diligent the efforts of conventional constitutional theorists to sketch the boundaries of judicial review, the courts will inevitably engage from time to time in a self-conscious process of making policy under the guise of interpreting the Constitution's indeterminate clauses, and in a government run by human beings, that effort should hardly surprise us. The occasional policymaking by judges should, however, be understood in its broader context. Since scholars (and students) usually debate only the tough cases, it is tempting to believe that all the cases are tough ones. Sometimes judges do indeed engage in a conscious effort to make policy, manipulating doctrines to fit their preferred views. But it would be a mistake to claim that they always or even usually do so. Alexander Bickel was no doubt correct in urging that the courts are more limited than the other branches in their ability to make policy, ${ }^{165}$ and the socialization of judges-a facet of liberal constitutionalism too important to overlook-is such that they do not always try. ${ }^{166}$ Very often, precedent

Law Review piece, see Fiss, supra note 65, that I criticized above, see supra pp. 838-39.

164. For a disdainful commentary that seeks to deny its disdain, see Posner, The Present Situation in Legal Scholarship, 90 YALE L.J. 1113, 1113-19 (1981). For a disdainful commentary that admits its disdain, see Tushnet, Deviant Science, supra note 18; cf. Tushnet, Post-Realist Legal Scholarship, 1980 WIS. L. REv. 1383, 1401 ("positive analysis has only been a detour").

165. See generally A. BICKEL, LDB, supra note 73.

166. Thus although Justice Rehnquist and Justice Brennan may disagree on many issues that come before the Supreme Court, those issues represent only a tiny corner of what the courts do. 
really does govern, and in precisely the fashion that law students are told that it does. Case $\mathrm{X}$ is more like Case $\mathrm{Y}$ than it is like Case $\mathrm{Z}$, so the rule of $\mathrm{Y}$ is applied to the case at hand. For all the classroom talk about doctrinal incoherence, the legal theories that students are taught (with the possible exception of the "fundamental rights" strand of constitutional law) really do serve as good predictors, as Holmes might have said, of what the authoritative interpreters will do in fact. ${ }^{\mathbf{1 6 7}}$

The law, in other words, is often settled, and when the law is settled, the authoritative interpreters-judges-usually accept it. That is one reason that their disagreements make headlines. The law may not always be settled correctly, and the delegitimizers are certainly correct in stressing that "settled law" frequently incorporates substantive biases. But adjudication under the Constitution's less determinate clauses need not be completely value-free, as long as the system of checks and balances continues to function, and as long as adjudication under the more determinate clauses is as value-free as we can make it. The fact that the values underlying judicial interpretations of the less determinate clauses may sometimes be bad values only illustrates what I said earlier: The system of checks and balances is not and does not need to be a perfect one. To satisfy the charges of delegitimizing critics that judicial review is ultimately an arbitrary arrogation of power inconsistent with the liberal ideal of a knowable, enforceable law, constitutional theorists need not demonstrate, I think, that the system is seamless or a thing of surpassing beauty. Beauty is fine when art is at issue, but when considering a government, what matters in the end is ability to function in a manner consistent with its stated ideals. This analysis might seem to prove the legitimacy of any functioning government, regardless of its ideals. The ideology of liberalism, however, preserves the right of the observer to stand outside the system and condemn the ideals-a freedom without which there would be no social progress. ${ }^{168}$ Once the system's ideals are accepted (and I shall

Witness, as evidence, the majority of petitions for certiorari, which are denied without comment-and the far vaster number of cases which are never appealed. Even a cursory review of denied petitions will quickly reveal how many of them are utterly without foundation. For anyone who believes that the Justices cannot possibly give fair consideration to the four thousand or so petitions disposed of each year, I recommend such a reading.

167. See O.W. Holmes, The Path of the Law, in Collected Legal Papers 167, 173 (1920): "The prophecies of what the courts will do in fact, and nothing more pretentious, are what I mean by the law." Nothing in this argument should be taken as a response to the more general delegitimizing contention that law, even in its apparent adherence to precedent, reinforces the existing order. See Dalton, An Essay in the Deconstruction of Contract Doctrine, 94 YALE L.J. 997 (1985); see also supra note 118. My argument on judicial socialization and the predictive value of precedent, like the rest of the Article, is a reaction only to the more limited argument that constitutional adjudication is inconsistent with the tenets of liberal constitutionalism.

168. Here again, a self-conscious reference to natural law might reveal that the saciety's expressed ideals are themselves pernicious. Government function is important as a test when the liberal observer, standing outside the system, finds its ideals acceptable and consequently chooses to enter into society. 
have more to say on the subject in a few paragraphs), it should be enough that all exercises of power are subject to constraint, that the system of checks and balances really does work, even if that working consists of rumbling and clunking along with a ferocious noise and great clouds of smoke-as long as the noise and smoke are signs of energy, not mere masks for disintegration and decay. So, unless one expects the perfection that Justice Walker correctly called unattainable, ${ }^{169}$ it ought to be enough, in short, that the system provides a means for muddling through.

As long as the system of checks and balances functions, any conscious or unconscious efforts by judges to make policy can occur only within its confines. The courts are a part of the government, and making policy is what a functioning government does. Thus, the courts are not alone in making policy. On the contrary: Bounded as they are by their socialization and by the checks placed on them by the nature of the system, judges make an amount of policy that must be termed minuscule in comparison with the policy made by the other branches. As long as the continuing interplay among the branches is well understood, as long as that interplay serves to check the powers of all the branches, and as long as judges are socialized away from the freewheeling imposition of their own ideas and values, then the intermittent making of policy by the judges poses no real danger to constitutional democracy.

The "as long as" in the previous sentence obviously cloaks a series of assumptions. The occasional judicial policymaking is legitimate only if the system really does work as I have described it, and only if the norms for interpreting the Constitution's more determinate clauses really are as plain as I suggest. Intellectual honesty compels me to admit that this approach to the questions raised by the delegitimizers demands from the reader a leap of faith. In order to accept the notion that the system of checks and balances can really perform the task that I have set for it, one plainly must believe in the knowability of some form of the original conception with respect to the provisions of the political Constitution. Much more important, however, one must believe in the goodness and ultimately the viability of the American constitutional democracy. This presupposition might seem at first blush to render the entire argument somewhat tautological, but at this point in the analysis, preference for one political system over another will inevitably play a role. A critic who unswervingly believes that the incoherence of liberalism must ultimately lead to injustice in the liberal state will never be swayed by my argument.

As will become clear momentarily, I realize that this means that an observer's judgment of both the American political system and judicial review under the Constitution will ultimately depend on the observer's judgment of American ideals.

169. See supra p. 821 \& note 1. 
In one of those lovely ironies so characteristic of political argument, this conclusion is compelled by the ideology of liberalism itself. Liberalism is at bottom an individualistic philosophy of politics, and proclaims the ultimate freedom of an observer to stand outside the system and criticize its stated ideals as well as its ability to realize them. This freedom is the most important bulwark an individualistic and yet process-oriented philosophy is able to offer against oppression; even in the liberal state, the highest morality is not always the morality of process. ${ }^{170}$ The liberal who already admires the ideals of the American democracy will be satisfied that the delegitimizing critique has been refuted, once convinced that the institution of judicial review and liberal constitutionalism are not inconsistent with the principles of liberalism. Since the delegitimizing critic may not accept the principles of liberalism, a refutation of this aspect of the critique (and I do not pretend to have refuted it here) would not refute the more general critique of liberalism as an ideology. This is not the place to discuss the relative advantages of liberalism and other ideologies. I will say only that the form of delegitimizing critique to which I am here responding argues that judicial review is inconsistent with the tenets of liberalism; thus it should not be necessary to present a defense of liberalism itself in order to suggest avenues for defeating the critique. Still, I should add that the paths I recommend rest on an assumption of the inherent goodness, or at least the open-mindedness, of human beings-an assumption that might be naive. For reasons that should be clear, if the people, who theoretically govern the liberal state, are either brainwashed or essentially mean-spirited and unembarassed about it, then much of my proposed analysis will break down. My leap of faith comes in assuming that neither is the case.

Naive or not, the leap of faith raises a clear question: Does this system of checks and balances truly provide the means for muddling through? It does so only if there really is a functioning system of checks and balances, because that system, the heart of the political Constitution, can do what it is designed to do only if it is established by relatively determinate clauses susceptible to interpretation under rules that are relatively clear. It is, in short, the law regarding the system of checks and balances and the rest of the political Constitution that must be shown to be knowable in a fashion not significantly dependent on the values of the judges. Thus, constitutional scholarship that seeks to refute the case put by the delegitimizers

170. This phrasing is inspired by, although it disagrees with, Alexander Bickel's famous dictum: "[T] he highest morality almost always is the morality of process." A. BiCKEL, MoRAl.rT, supra note 82 , at 123 . 
ought to eliminate the need for-or at least to shorten the length of -the leap of faith that I have described. Scholarship should focus on the relationships among the branches of government or between the government and the people, because in no other way can it be demonstrated that the system works. The assault will never be repulsed through attempts to uncover (not create) enduring interpretive principles of such clarity and neutrality that they will leave the critics breathless with admiration. There is a need for scholarship on the best way of construing the equal protection clause or the Eighth Amendment, but that is the real-world need for deciding real cases involving real people. The mistake is in assuming that scholarship of that kind will refute the delegitimizing critique of judicial review.

Scholarly investigation of the system of checks and balances might ultimately reveal that there is no functioning system, or, perhaps as troubling, that there really are no interpretive norms both easy of application and wide in acceptance. If there is no system, if there are no norms, then the delegitimizers might win the day. But that possibility is hardly a reason not to try. The fact that the government survives and continues to operate-if it is a fact-provides reason to believe that legitimacy even of the muddle we call government can finally be demonstrated. And it is surely best in any case for conventional theorists to approach the challenge as optimists, saying with Casey Stengel, "They said it couldn't be done, but sometimes it doesn't always work."

And if we do fail-if constitutional adjudication really does prove to be no more than an incoherent part of an incoherent system-then perhaps there will be no moral alternative to sweeping the Constitution away. I doubt that we will sweep it away even then, however, for the American people and their ideology have proved remarkably resilient over the past two centuries, conquering civil war, industrial revolution, and economic depression without coming apart. I suspect that even if all the conventional constitutional theorists were to reject conventional theory, the rest of society would continue to muddle through, which might not, in our second-best world, be so terrible a thing.

To explain why, I return to the myth of Sisyphus. Should the delegitimizing critique in the end prove irrefutable, those of us who want to do conventional constitutional theory may seem doomed, as was Sisyphus, to push the boulder to the top of the mountain, only to find it tumbling down once again. But the message that muddles come in different kinds should not be forgotten: Not all muddles are the same. As Albert Camus suggested, Sisyphus need not despair even should he discover that his task 
lacks the significance that he might have hoped for it: "The struggle itself toward the heights is enough to fill a man's heart."171

The first step to a better tomorrow is to recognize the truth about today.

171. A. Camus, The Myth of Sisyphus, in The Myth of Sisyphus and Other Essays 1, 123 (1969). 
HeinOnline -- 94 Yale L. J. 873 1984-1985 


\section{The Yale Law Journal}

Volume 94, Number 4, March 1985

\author{
Mark E. Haddad \\ Editor-in-Chief \\ Beth S. Brinkmann \\ Julia E. Guttman \\ Peter D. Keisler \\ Sarah Korn \\ Robert A. Long \\ Note Editors
}

\author{
Amy L. Henrich \\ Managing Editor \\ Lynn A. Baker \\ Anita Bernstein \\ Ronald D. Lee \\ Howard M. Shapiro \\ William M. Treanor \\ Article $\mathcal{E}$ Book Review Editors
}

\section{Senior Editors}

Pauline E. Calande

Sharon A. Hooper

Niki Kuckes

John R. Low-Beer
David A. Martland

Emily S. McMahon

John B. Sandage

Gene C. Schaerr

Paul Schwartz
Gene B. Sperling

Peter P. Swire Stephen H. Willard

Wendy A. Wolf

\section{Editors}

Robert S. Adelson

Thomas P. Arden

David M. Aronowitz

Patrick A. Broderick

Kenneth Christman

Stephen M. Cutler

David R. Dow

Deborah D. Dupire

Peter R. Ezersky

Sarah B. Gordon

Rosemary Herbert

Alan Hirsch

Kenneth C. Johnsen

Howard Kruse

Ronald J. Kuerbitz

Christopher C. Magorian
David C. Marcus

Kathleen L. Roin

Reva Siegel

A. Clayton Spencer

W. Danforth Townley

Stephen A. Warnke Jack Wenik Songyi Zhang

Business Manager: Pamela Standish Editorial Assistant: Rosemary B. Carey

\section{Student Contributors to this Issue}

Robert S. Adelson, Third Party Beneficiary and Implied Right of Action Analysis: The Fiction of One Governmental Intent

Patrick A. Broderick, Conditional Objectives of Conspiracies

Kenneth C. Johnsen, Golden Parachutes and the Business Judgment

Rule: Toward a Proper Standard of Review

Reva B. Siegel, Employment Equality Under the Pregnancy

Discrimination Act of 1978 